Bueno Ramírez, P., Barroso Bermejo, R., De Balbín Behrmann, R. y Salvado, P. (2019):

"Stone Witnesses: armed stelae between the International Tagus and the Douro, Iberian Peninsula". Spal 28.2: 143-164. DOI: http://dx.doi.org/10.12795/spal.2019.i28.17

\title{
STONE WITNESSES: ARMED STELAE BETWEEN THE INTERNATIONAL TAGUS AND THE DOURO, IBERIAN PENINSULA
}

\author{
TESTIGOS DE PIEDRA: ESTELAS ARMADAS ENTRE EL TAJO \\ INTERNACIONAL Y EL DUERO, PENÍNSULA IBÉRICA
}

\author{
PRIMITIVA BUENO RAMÍREZ \\ Área de Prehistoria. Facultad de Filosofía y Letras. Universidad de Alcalá de Henares. C/ Colegios 2, 28801, Alcalá de Henares, Madrid Co- \\ rreo-e: p.bueno@uah.es. (D https://orcid.org/0000-0001-8958-8928 \\ ROSA BARROSO BERMEJO \\ Área de Prehistoria. Facultad de Filosofía y Letras. Universidad de Alcalá de Henares. C/ Colegios 2, 28801, Alcalá de Henares, Madrid Co- \\ rreo-e: rosa.barroso@uah.es. D https://orcid.org/0000-0003-3129-4497 \\ RODRIGO DE BALBÍN BEHRMANN \\ Área de Prehistoria. Facultad de Filosofía y Letras. Universidad de Alcalá de Henares. C/ Colegios 2, 28801, Alcalá de Henares, Madrid Co- \\ rreo-e: rodrigo.balbin@uah.es. (D) https://orcid.org/0000-0002-3947-5308 \\ PEDRO SALVADO \\ Museo Arqueológico José Monteiro. R. do Serrão 15, 6230-378 Fundão, Portugal. \\ Correo-e: geralmuseu@cm-fundao.pt
}

Resumen: Pocos territorios en Europa reúnen la concentración de estelas en piedra que se documentan entre el Tajo y el Duero. La arqueología asegura amplias posibilidades extractivas, con un claro centro neurálgico en el actual distrito de Castelo Branco. Desde los primeros descubrimientos de piezas tan singulares como las de São Martinho, hasta el registro actual, la variedad y diacronía de estelas y menhires en piedra resulta excepcional en el contexto ibérico y europeo. La tradicional lectura, que alejaba los viejos menhires de las estelas del Bronce Final, queda muy matizada ante el uso de referencias temáticas y técnicas semejantes. En este texto aportamos otro argumento a sumar a esas similitudes, con la reutilización de los antiguos soportes como base material para la generación de las estelas del Bronce Final. Las imágenes humanas que se grabaron en estas memorias en piedra expresan narrativas sociales elaboradas. Las secuencias gráficas que argumentamos aseguran el papel político de estas piezas como justificaciones materiales de pasados ancestrales. Indudablemente albergan relatos orales sobre la relación entre los viejos ancestros y los nuevos líderes, justificando el orden del entramado económico asociado al control de la extracción y comercio del metal.

Palabras clave: Estelas, Menhires, Memoria, Neolítico, Calcolítico, Bronce.
Abstract: Few places in Europe concentrate as many stone stelae as the area between the Tagus and the Douro. Archaeology has shown the ample possibilities for metal mining, the modern region of Castelo Branco being the epicentre in the area. From the first discoveries of such unique objects as the São Martinho stelae to the current record, the variety and diachronicity of stone stelae and menhirs is exceptional on the Iberian and European scales. The traditional interpretation that differentiated between the old menhirs and Late Bronze Age stelae has been nuanced by the evidence of similar themes and techniques. Another argument presented here is the use of the old stones as the basic material to produce the Late Bronze Age stelae. Human images carved on these memorial stones express elaborate social narratives. The graphic sequences described here demonstrate the 'political' role of these stones and material justification of ancestral pasts. They were undoubtedly imbued with oral tales about old ancestors and new leaders, to justify the order of the economic system associated with mining and metal trade.

Keywords: Stelae, Menhir, Memory, Neolithic, Chalcolithic, Bronze Age. 


\section{INTRODUCTION}

The consolidation of human images on stones documented in European Late Prehistory is markedly significant in the Iberian Peninsula; from the first Neolithic menhir to Protohistoric stelae, with evident continuity in the representation of warriors associated with the late first millennium cal BC.

Our research in this field has been aiming to demonstrate the establishment of anthropomorphic representations at the time of the first farming communities. Equally important is their role as undeniable models in the production of the more recent images. Not only their materiality is of great significance, but they also co-exist in the same necropolises, sharing ritual places that made their role as memories in visible stones (Barroso et al. 2007, Bueno Ramírez 1990, 1992, 1995, Bueno Ramírez et al. 2005a, 2010a, 2011a, 2011b, 2018a).

Within this long period of time, two turning points are perceptible from chronological and cultural perspectives. One is associated with old menhir and stelae that formed one of the ideological foundations of the first megalithic monuments. The other one is related to the creation of the armed stelae from the third millennium cal BC onwards. Therefore, the times between the sixth and fifth millennia cal BC, and the third millennium, are fundamental to answer some of the questions about these images. Similarly, the confirmation that some of the Late Bronze Age stelae were reused megalithic stones or menhir and older stelae adds a new element to reflect on the exhibition of the past and the ideology that underpinned the social construction of these images.

Reusage of megalithic stones continued in later productions, both in the monuments and for portable objects found within the grave goods (Bueno Ramírez 1995: 128, 2010, Bueno Ramírez et al. 2015a, 2015b, 2016, Díaz-Guardamino 2010, Jones et al. 2015). It was precisely this constant reuse throughout Prehistory and Protohistoric that resulted in an accumulation of the past within sculptural representations. They were imbued with transversal biographies that survived and adapted not only to different chronologies but to diverse typologies and contexts, as they became ideological references at the end of Protohistory and the start of History (Bueno Ramírez et al. 2005a: 639).

Within the wide territories in the Iberian Peninsula where armed representations have been found, some areas have stood out since the first discoveries. The plains between the International Tagus and the Douro, in the middle basins of the two rivers that cross the whole of inland
Iberia (Northern and Southern Meseta) and flow into the Atlantic. The Castelo Branco district coincides approximately with this area. Its wealth of metal seams is wellknown, as well as its dense population, which becomes especially visible from the third millennium cal BC onwards (Bueno Ramírez et al. 2004, Henriques et al. 2011, Vilaça 2000). Access to the Guadiana and Guadalquivir valleys, or to the Algarve or northern Portugal, is rapid and easy from this area.

This area displays certain elements enabling a reflection on some of the classic aspects of the origin of megaliths. One of them is the diachronic use of the monuments and their association with stelae, menhir and small human images. The other one is the persistence of the ancestors' ritual during the Bronze Age. Craftsmanship, specialisation, identities and tradition can be seen in these artefacts. They also provide evidence about the social importance of the exhibition of human figures throughout several millennia. We might also reflect on the meaning of the anthropomorphic references' variability (fig. 1).

\section{CULTURAL TRAJECTORIES AND HISTORIES OF STONE IN THE CASTELO BRANCO DISTRICT}

The São Martinho stelae at Monsanto (Salvado and Batista 2016) are one of the historiographic landmarks in the series of Bronze Age stelae that regarded as an ensemble since Almagro Basch's repertoire (1966). They were always considered unique in the Iberian Peninsula, because of their complex decoration did not corresponding exactly with the most classic cases (Araque 2018, Celestino 2001, Díaz-Guardamino 2010). The different phases of engraving on the Castelo Branco stelae (studied by Bueno Ramírez et al. i.p.) enrich the importance of the abovementioned return to the past in Protohistoric stelae. The major role of this district in the production of armed images in south-west Iberia during the Chalcolithic confirms the importance of the third millennium cal BC, especially its second half.

This area displays a long tradition of human occupation, including sites with Palaeolithic decoration (Bueno Ramírez et al. 2010b, Gomes 2007) and Epipalaeolithic occupations associated with rock art and burials (Oliveira et al. 2014, Cerrillo et al. 2015). Other finds include early Neolithic populations, fortified settlements, painted rock-shelters, engravings in the open air, menhir and stelae. These finds are beyond the scope of this paper. However, this accumulation 


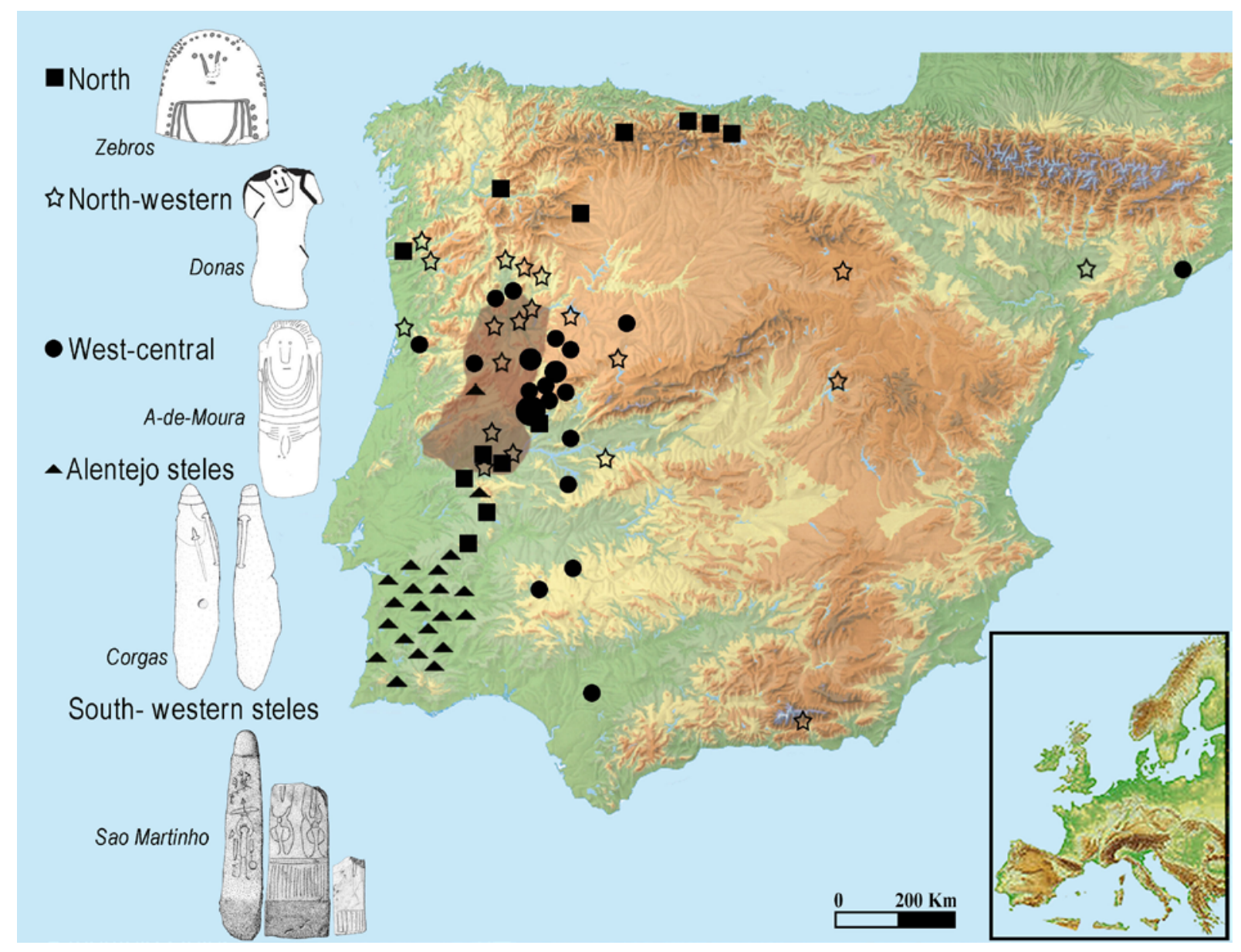

Figure 1. Plan with different types of stelae in Iberian Late Prehistory (schematic images without scale), and the area of study in black, after Bueno et al. 2011.

of evidence in the western plains between the Tagus and the Douro establishes this area as the area with the greatest potential in southern Europe, despite the classic interpretation of unoccupied regions until later times in Protohistory (Bueno Ramírez et al. 2004, 2008a, Oliveira 2011, Oliveira and Oliveira 2000, da Silva and Soares 2012).

Megalithic monuments codified architectures through a required social consensus and cohesion, both for their construction and for the different stages of their use and maintenance. Their abundance in this district has been exponentially increased in recent years as the result of intense research on both banks of the Tagus, especially after the late 1980s and 1990s (Bueno Ramírez 1988, 2000, Bueno Ramírez et al. 1998, 1999a, 2006a, 2006b, 2007a, 2012, Caninas et al. 2004, Cardoso et al. 1995a, 1997, Oliveira 1998, Scarre et al. 2011) (fig. 2).
It is symptomatic that all the periods in recent Prehistory are associated with human images in stone, of various typologies, sizes and positions. This association is quite revealing. Moreover, centres where these images were produced in Late Prehistory Europe are constantly linked with areas of mining or quarrying: flint in southern France, salt on the European plains, copper on the Mediterranean islands. This also seems to be true throughout this district, with its potential for gold, copper and tin (Barroso et al. 2003 and 2017, Bueno Ramírez et al. 2004, Robb 2009).

The situation is the same in the Bronze Age. Some studies in Extremadura in the 1970s (Almagro Gorbea 1977), only partly updated (Martín 1999) still need to be followed up. In contrast, in Portugal, the steady documentation of habitats and metal finds has changed the panorama. This used to be a 'poor' district and it is now one of the places where we need to consider the potential for 

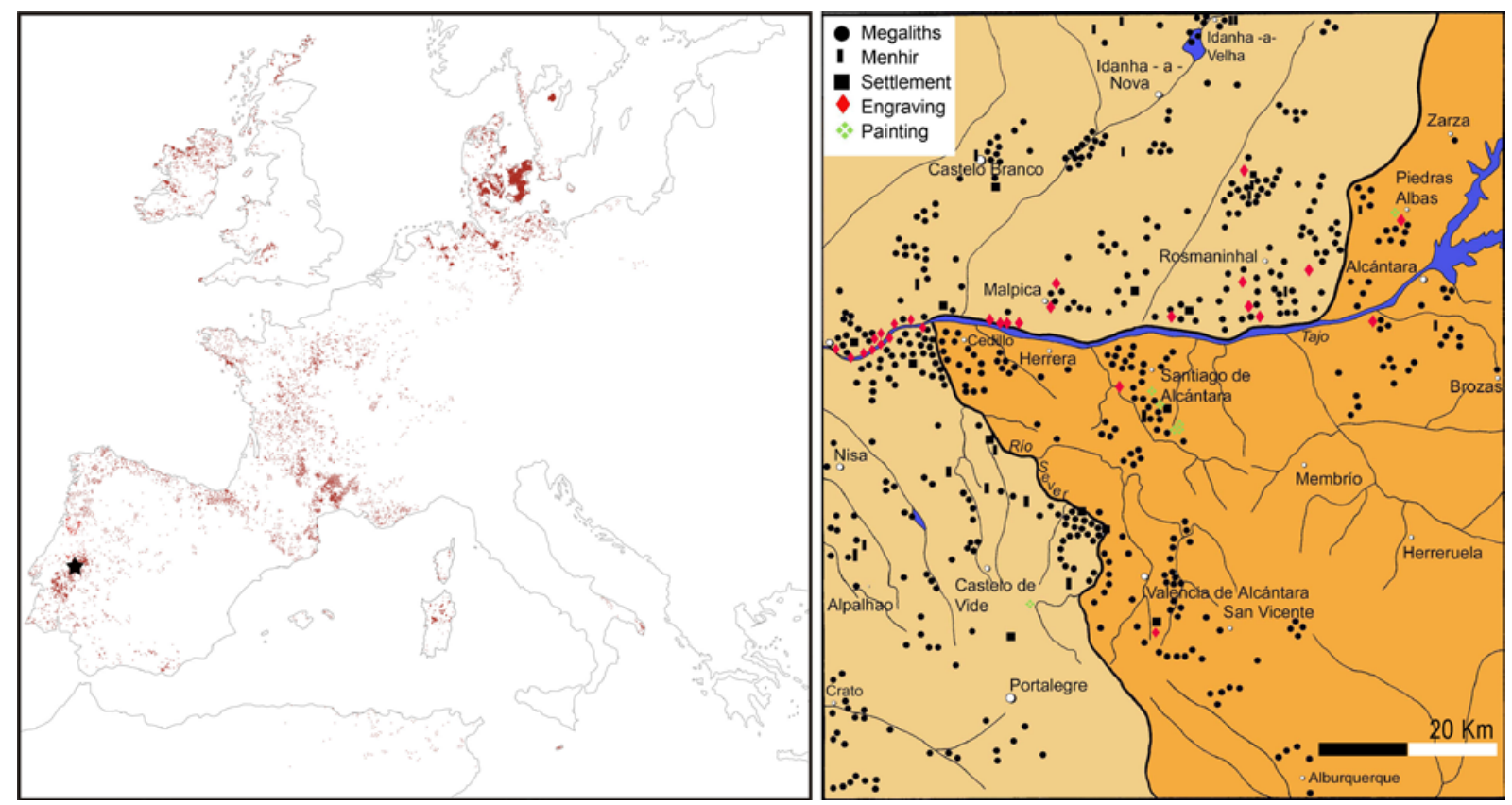

Figure 2. Left: Megaliths in Europe, after Laporte and Bueno ,2016: Right: Megaliths and the other sites of megalithic builders between Tagus and Douro actualised after Bueno et al. 2004.

the distribution of fluvial gold (Barroso et al. 2003, Bueno Ramírez et al. 2004, Henriques et al. 2011), copper and bronze metallurgy, and the early date of the use of iron (Vilaça 2013). This period is equally accompanied by representations in stone, from the first armed figures that are chronologically connected with the stelae in Alentejo, to the better-known objects in the series of south-western stelae. The latter are significantly represented quantitywise in the district (Vilaça et al. 2011a).

Coinciding with the end of the characteristic Iberian Neolithic and Chalcolithic portable representations, the armed stelae bring together social exhibitions of great visual impact. These remain as the 'mark' of accumulated pasts to enrich the images of the new late Bronze Age hierarchies. The stelae of Longroiva, Corgas, Telhado and Monte dos Zebros (Banha et al.,2010, Bizarro et al., 2016, Cardoso 2011), together with the nearby ones at Lagunita I, Garrovillas (Bueno Ramírez et al. 2011b), Valencia de Alcántara, Alcántara and Hernán Pérez (Bueno Ramírez 1992, Bueno Ramírez and Vazquez Cuesta 2009), and evidently the famous group at São Martinho, confirm that their material references recuperated ancestral representations. Our hypothesis is about the value of these stelae as megalithic memory and thus it acquires significant quantitative and qualitative support (Bueno Ramírez et al., 2005a: 617, Bueno Ramírez et al., 2010a).
This district was traditionally viewed as if it had no archaeological interest, even depicted as agriculture-less. This idea has been maintained until practically the start of the new millennium (Oliveira 2000). We currently have powerful arguments in favour of more complex understandings through the study of the anthropomorphic representations. On one hand, we ought to consider the personality and workshops of the decorated plaques in the structured deposits, and the importance of the technical and symbolic formulae of these representations over Neolithic and Chalcolithic statues (Bueno Ramírez 2010). On the other hand, we must reflect on the Mediterranean contacts visible through large sculptures in triangular shapes, that maintain ancestral references (type of material used and fabrication methods). They are solid evidence for the social and ideological background of these groups (Bueno Ramírez 1990, 1992, 2010, Bueno Ramírez et al. 2005a, 2010a, Henriques et al. 2012, Vilaça et al. 2011a). The exceptionality of the Castelo Branco stelae (as well as all the works published since their discovery), is precisely their role as stone witnesses for the ancestors' memories persistence. Indeed, it is these references that justify their millennial value (Bueno Ramírez et al. i.p.).The western Tagus valley can therefore be included in the debate about population stability in the Iberian Peninsula. This landscape 
is one of the clearest facets of connectivity in recent Prehistory, at least since the Neolithic, in the light of the latest discoveries.

A Prehistory constructed based on absences and marginal groups is seen in the same way as the latest research on the European plains. The idea is that there are territories with great social availability, play a key role in new cultures, and this is as important as how they manage the movement of raw materials and ideas. The Iberian Peninsula is definitely one of the most relevant of these territories in Europe. The Mediterranean influence, noted since the 1990s in Chalcolithic statuary, has now been clearly documented in the area of Andalusia through the identification of amber from Sicily and ivory from Africa and Asia (Bueno Ramírez 1990, 1992, 1995, García Sanjuán et al. 2013, Schumacher and Banerjee 2012). Figures of undeniable visibility have only been demonstrated in the area. Thus, it is likely that the territory between the Tagus and the Douro was important for the distribution of certain raw materials. As noted above, its metallurgical wealth is well known and the Castelo Branco district is one of the most important case studies in south-west Iberia, together with places in the area of Huelva (Vilaça 2004a).

\section{STELAE, MENHIRS, STANDING STONES. DIACHRONIC INTERPRETATIONS}

The confluence of similar ways of fabricating, profiles and roles among stelae, menhir and standing stones suggests a reassessment of the way we classify each of these versions as a separate entities (Bueno Ramirez 1990, 1992, 1995). The convincing attribution of these stones to human images that, decorated or else, alludes to ancestors, is increasing in popularity in European megaliths' studies. They appear in open-air structures (cromlechs, alignments, etc.) as well as indoor monuments, attesting to a much more common inter-relationship than classic historiography admitted. Sequences of menhir and dolmens in the first phases of megalithic constructions are well known. Likewise, they exist during the whole chronology of the monuments and contribute to complex construction, repair, maintenance and closure processes. The stones (standing stones, stelae and menhir) played and essential role for the ideological discourse that was manifested through the funerary rituals (Bueno Ramírez et al. 2008b, 2015a, 2015c, 2016, 2018b, Laporte, 2010, Laporte et al. 2017).

The peak period for of these processes cannot be separated from the great age of some menhir and stelae, and of some standing stones. The current state of art suggests that symbolic differences between the early and middle Neolithic ideological products are shortening. The ideological and craftsmanship (ways of working) relationship between the first farmers' stone images and the megalithic constructions is not as great as it seemed (Bueno Ramírez et al. 2007b and c).

In this context, the shared distribution of these objects is another argument supporting the search for the repeated use of the same stones with anthropomorphic value. In our area of study, the Granja de Sao Pedro dolmen's menhir, known since the 1950s (Almeida and Ferreira 1958, Salvado and Baptista 1982) combine the elongated profiles of the narrow upper part and thicker sections with representation of lines and cupmarks, similarly to other old menhirs in the district. The recently documented Nisa menhir can be linked to those at Meada and Alcántara, of similar morphology and chronology in the early Neolithic (Oliveira 2016).

The inclusion of old stones in dolmens is another important factor that is being considered in recent studies. Our research at the megalithic site of Proença a Nova together with our colleague J. Caninas has succeeded in documenting the reuse of stones in Cabeço da Anta and at the Alvito dolmen. This is equally present in the megaliths in the area of the old Order of Alcántara in Caceres (Bueno Ramírez et al. 2008a).

Other aspects support this perspective, such as the size of the stones. Some of them measure nearly 5 metres and others are even larger (Meada). They contrast with the more standardised sizes in the Algarve and parts of the Alentejo, where they tend to be a maximum of 3 metres, with notable exceptions such as the stela-menhir of Anta Grande Zambujeiro (Soares and da Silva 2010). Only a few stones in the Iberian North reach that size (Bueno Ramírez et al. 2009a) and highlight the undeniable intention of long-distance visibility that seems to define this kind of monument. Other factors, such as the social relevance projected through with the size of the erected stones (menhir and stelae), their capacity for social recruitment and even their demography, are to take into account when reflecting on the collective labour that the search, choice, transport, erection and maintenance of these large stones required.

Their decoration is another outstanding factor. In general, they reiterate sinuous forms with low relief techniques associated with hafted axes, crooks and suns, together with human features, like faces and clothing on the stones that are classed as stelamenhir. The close relationship between menhir and stela-menhir is evident, especially if we consider 


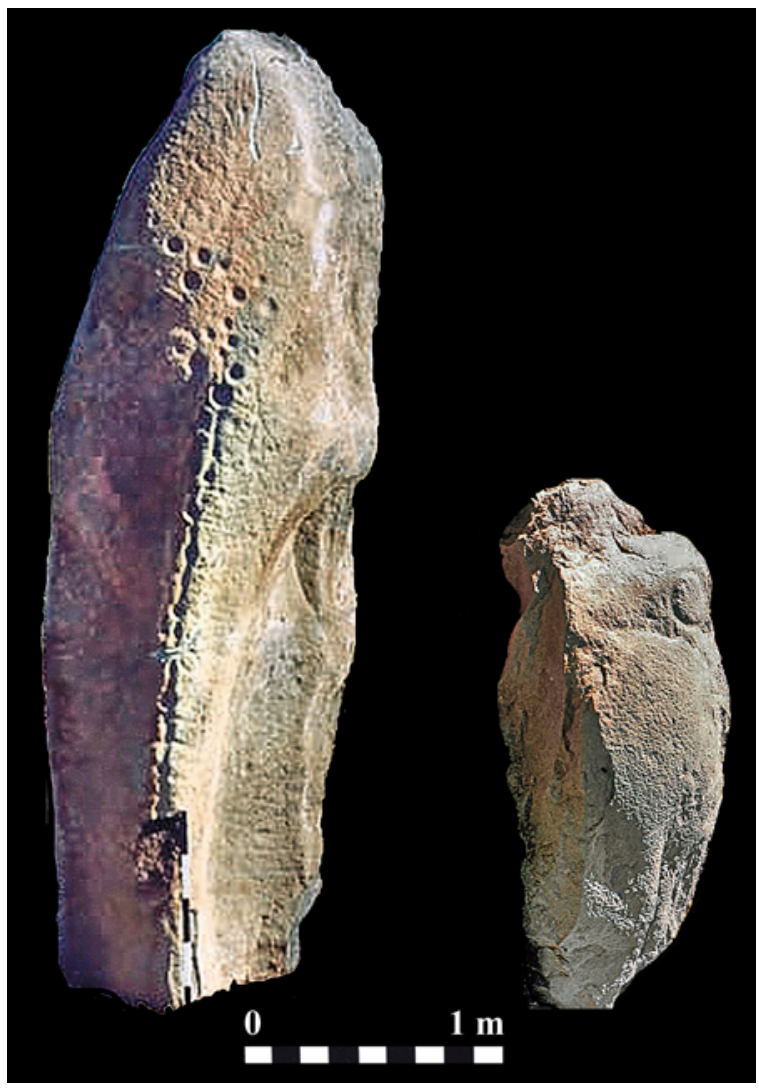

Figure 3. Menhirs 1 and 2 of Lavajo 1 (Alcoutim, Portugal) after Cardoso et al. 2002.

similarities in fabrication techniques, as in the Almendres menhir. In any case, this ensemble is clearly an anthropomorphic group linked to the diachrony of the megalithic monuments in the territories where they are located (Bueno Ramírez et al. 2015a and 2015b, Cerrillo et al. 2019).

If the engravings described above are compared with contemporaneous European productions (Calado 2002), especially the crooks and axes as well as the clothing (where the Iberian examples are quantitatively more important), the menhir in the International Tagus suggest another interesting point. Further south, the presence of stones decorated in local styles, such as the Lavajo menhir, closely related to the decorated megaliths in the area, and their predominant pecking technique, guarantee the Chalcolithic date. A good example is a plaque comparable to those that are found in megalithic deposits (Bueno Ramírez 2000, Cardoso et al. 2002, Cardoso and Gradim, 2011) (fig. 3). Thus the possibility of determining precise sequences within menhir groups is of greater interest. In fact, this is quite unique on a
European scale. Some examples documented in the South of France suggest long-distance links across the plains of central Iberia, as has been noted (Bueno et al., 2009a). We are referring to the menhir of Guillay, Landes (Beyneix 2007: 519) with a pecked schematic quadruped in the Tagus style.

Large stones are the basis of the third millennium cal $\mathrm{BC}$ armed representations. They reiterate the Alentejo stelae's weaponry but on stones that aspire to display their visibility in the same way as the older menhir. The difference between the tampas esculturadas, normally in a zenithally or sub-vertical position, and the statues that characterise the examples in the centre/north of Portugal and western Spain, establishes different readings of the funerary landscapes. The third millennium statues include the images of the oldest ancestors, repeating their sizes and even reusing old menhir to give them a new importance adding the weaponry of third millennium warriors. In this regard, the upper end of the Corgas statue (Banha et al. 2010) with its pointed apex and roll of the phallus is very similar to the classic top of the oldest menhirs described above (fig. 4). The same is true of the upper part of the São Martinho menhir (Diaz-Guardamino 2010), or Ataúdes stela-menhir in the near locality of Guarda (Vilaça et al. 2003) with weapons in an Alentejo stelae style.

The pointed ends of triangular stones are known as central uprights in some chambers in the Evora area (Anta de Mitra is a good example). They are comparable to one of the large stelae currently being documented in the area of the gate at Perdigões (Bueno Ramírez et al. in elaboration), as well as to the Longroiva stela, which has been interpreted as a reused stone (Bueno Ramírez et al. 2010a). Their format is identical to that of the peculiar stone at Telhado, which is quite different from the types of stones currently known for Late Bronze Age stelae (fig. 5). Thus, Corgas, Longroiva and Telhado could be old stones that were re-engraved to play a more visible role in this area of study. On the other hand, its outline reproduces that of a 'grinder', an aspect that is also associated to the Cegonhas menhir, in Idanha-a-Nova (Cardoso et al. 1995b), and that has relevant references in the European context (Graefe et al. 2009)

The systematic reuse of stones has been observed in many more cases of Chalcolithic and Bronze Age stelae: Millarón (Bueno Ramírez and Balbín Behrmann 1991), Cruz de Cepos (Alves y Reis 2011) with several reuses on an older stela, the Tameirón example (Comendador et al. 2011), the Baraçal 1 stela (Santos et al. 2011: 8), a possible stela with 
a defined head, the Aldea Velha stela (Vilaça et al. 2011b: fig. 4), re-engraved (as can be seen in the area of the head) over an older representation, the two stelae of Piedra da Atalaia (Vilaça et al. 2011a), where we appreciate the notorious of a possible angular bottom of Pedra da Atalaia I, and the fragmentation of an older engraving of Pedra da Atalia II.

Other menhir have been documented as the base of Late Bronze Age stelae (like Bayuela and Talavera de la Reina at Toledo, or Luna at Zaragoza), as well as the menhir known at Late Bronze Age/Iron Age sites (Rocha 2003) (fig. 6). A long tradition of elongated stones with phallic references in their upper part can be seen in the oldest Neolithic examples until the Iron Age. In addition, the confirmation that some of the stones were reused more than once emphasises the diachrony of human references as part of the interpretation of these monuments in the social settings that maintained them.

Parallel with this statuary, a large number of sculptural representations on stones include documented reiterations on decorated plaques, especially the sculptural types produced in workshops between the Tagus and the Douro, and as far as the Guadiana (the same areas that the Hurdes-Gata series occupies; Bueno Ramírez 1992, 1995). The chronology of the plaques is still documented in the third millennium BC (dolmen of Trincones, Alcántara) and that of the stelae is dated in a similar time. The close similarity of the representations on the stelaplaques and the central-western series has been noted on several occasions (Bueno Ramírez 1992, 2010, Bueno Ramírez et al. 1999b, 2011a, Bueno Ramírez and González Cordero 1995). The stela at Monte dos Zebros (Cardoso 2011), in our area of study, is a clear example of these connections. Recent works on the examples from the Montelirio dolmen, whose clay stela is quite similar to other examples in the area (especially Crato and Nossa Senhora da Esperança), does not only confirm the proposed chronology. It also reinforces the role of the inland plains between the Tagus and the Douro in the projection of symbolism associated with the greatest movements of raw materials and ideas in Late European Prehistory: the third millennium cal BC. We should not forget the impact of these approaches on places like Peña Tú and all the examples in northern Spain and their connections to Europe (Bueno Ramírez 2010, Bueno Ramírez et al. 2010a, 2015c) (fig. 7).

Finally, it should be noted that south-western stelae used the same type of stone as the series of centralwestern stelae: a dark raw material, normally schist, and flat medium-sized surfaces.

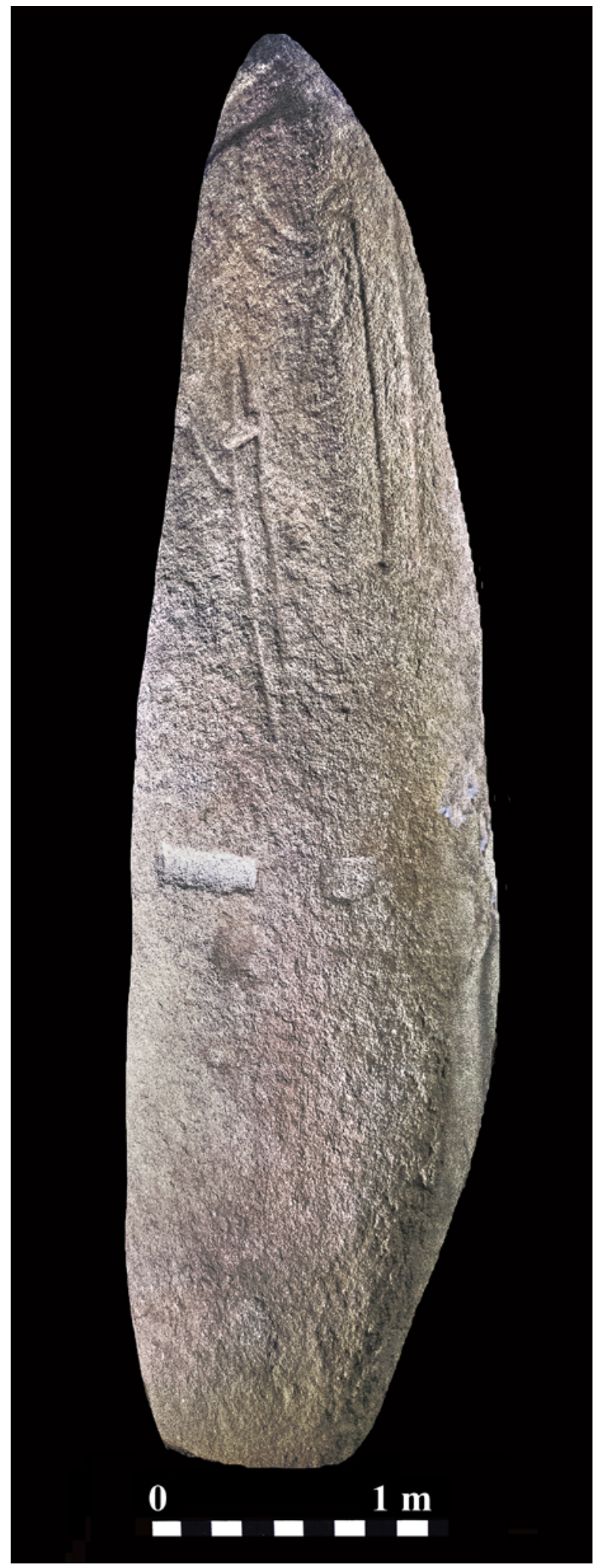

Figure 4. Menhir of Corgas, Fundão Museum, Portugal. Photo R. de Balbín Behrmann. 


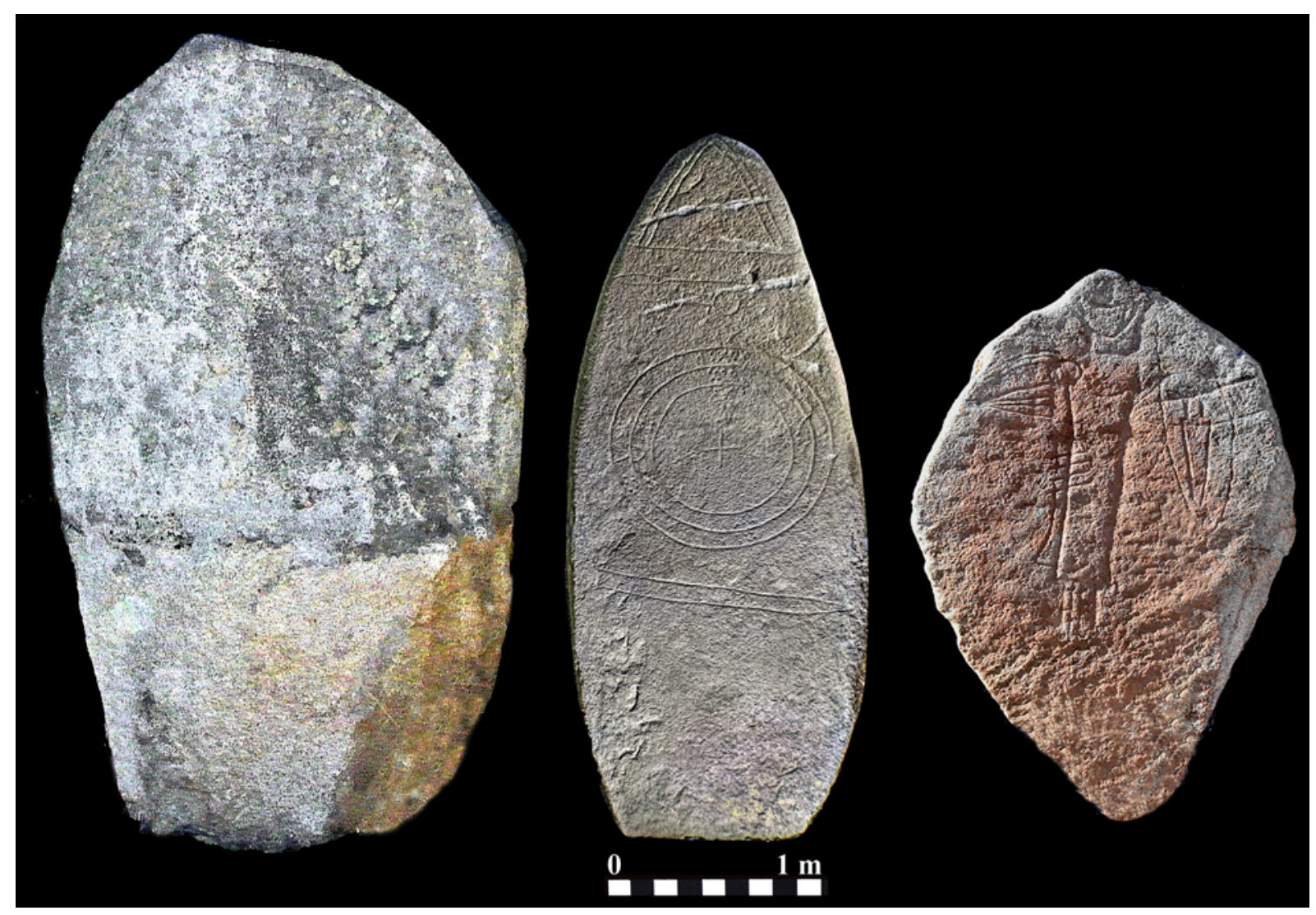

Figure 5. Central chamber uprigth of Anta de Mitra, Evora. Telhado Stela, Fundão Museum, Portugal. Longroiva Stela, Guarda, Portugal. Photos R. de Balbín Behrmann.

\section{THE CASTELO BRANCO STELAE:}

\section{ANCESTRAL BIOGRAPHIES SET IN STONE}

Together with their quantitative abundance and formal variety, two very important factors converge in the representation of human images in our area of study: their ancient age, especially for their singular versions in the megalithic landscape, and their age-old importance in the materialisation of power in a Protohistoric time (Bueno Ramírez et al. 2011b).

These two aspects are linked in some objects and contribute to a unique interpretation of graphic sequences. The stelae capture different times, fix their memories and offer fragments of the past that we can recuperate through the application of careful study protocols.

The famous group at Monsanto is a clear case of the reuse of old stones. Abundant literature has been produced about them since their discovery because of their unique nature in the south-west, their geographic position and the close association of three stones that are apparently very different. The opportunity of examining them in detail at their current location in Castelo Branco Museum enabled an assessment of some of the points mentioned above: the impact of old uses, the maintenance of modules with visibility in mind and the exhibition of these stones in places of great ritual significance.

The first phase of graphic activity is evident on stelae I and III of Sâo Martinho (fig. 8), with forms that are recognisable in central-western stelae, especially in the style of the example from Granja de Toniñuelo (or Nave and Zebros) which displays interesting connections with Stela I. Both were fabricated in granite. Belts depicted with a single line or two, with an inner fill of dots, are associated with clothing, probably with folds or geometric adornments like the better-known examples on the megalithic stelae in the South of France (Maille 2010). Light engraving of a semi-circular face associated with necklaces in the upper part of stela I, together with the semi-circular carving of part of its right side with a fill of incised angular motifs, contribute to define this first engraving phase. On Stela III the 


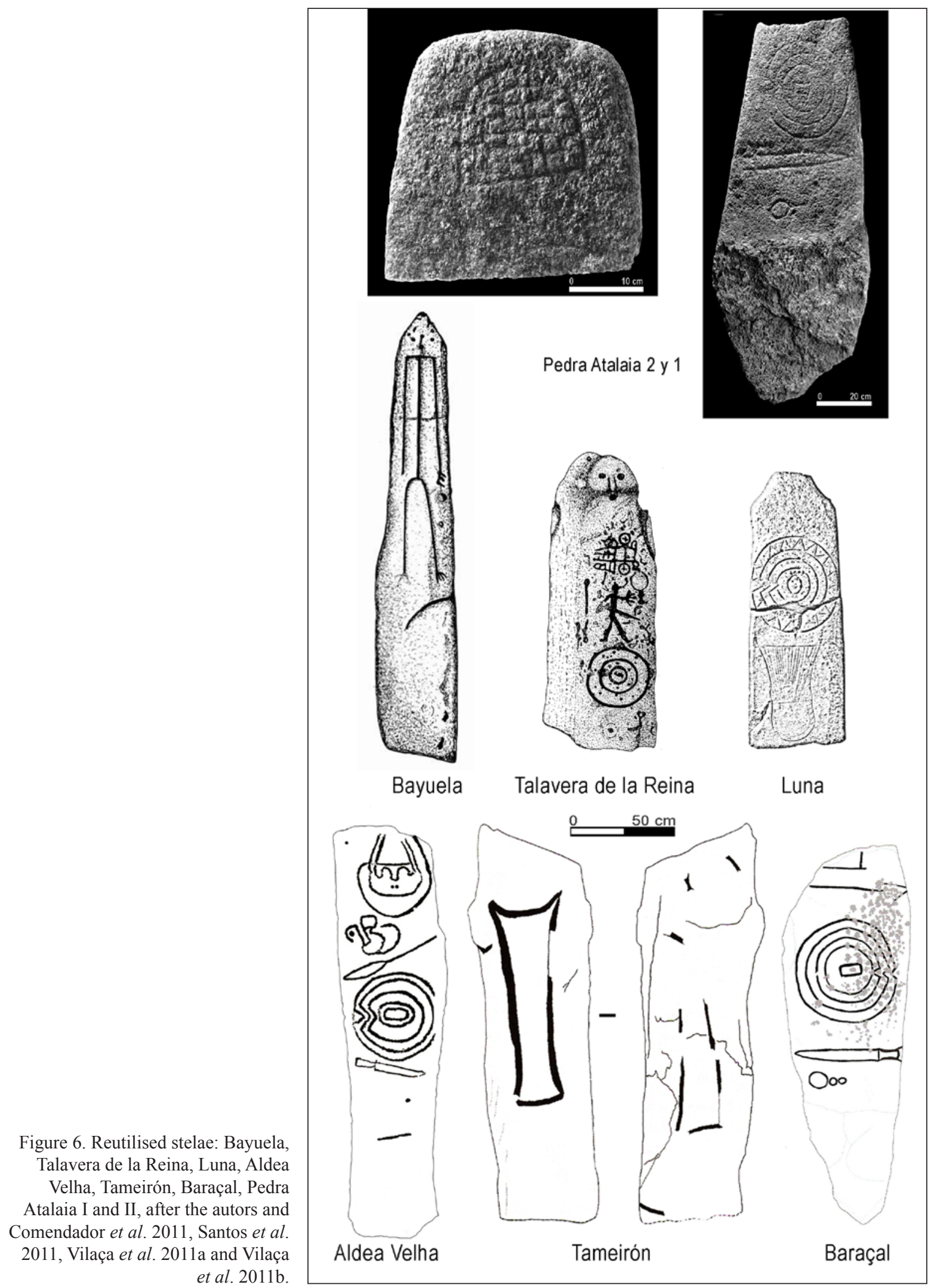




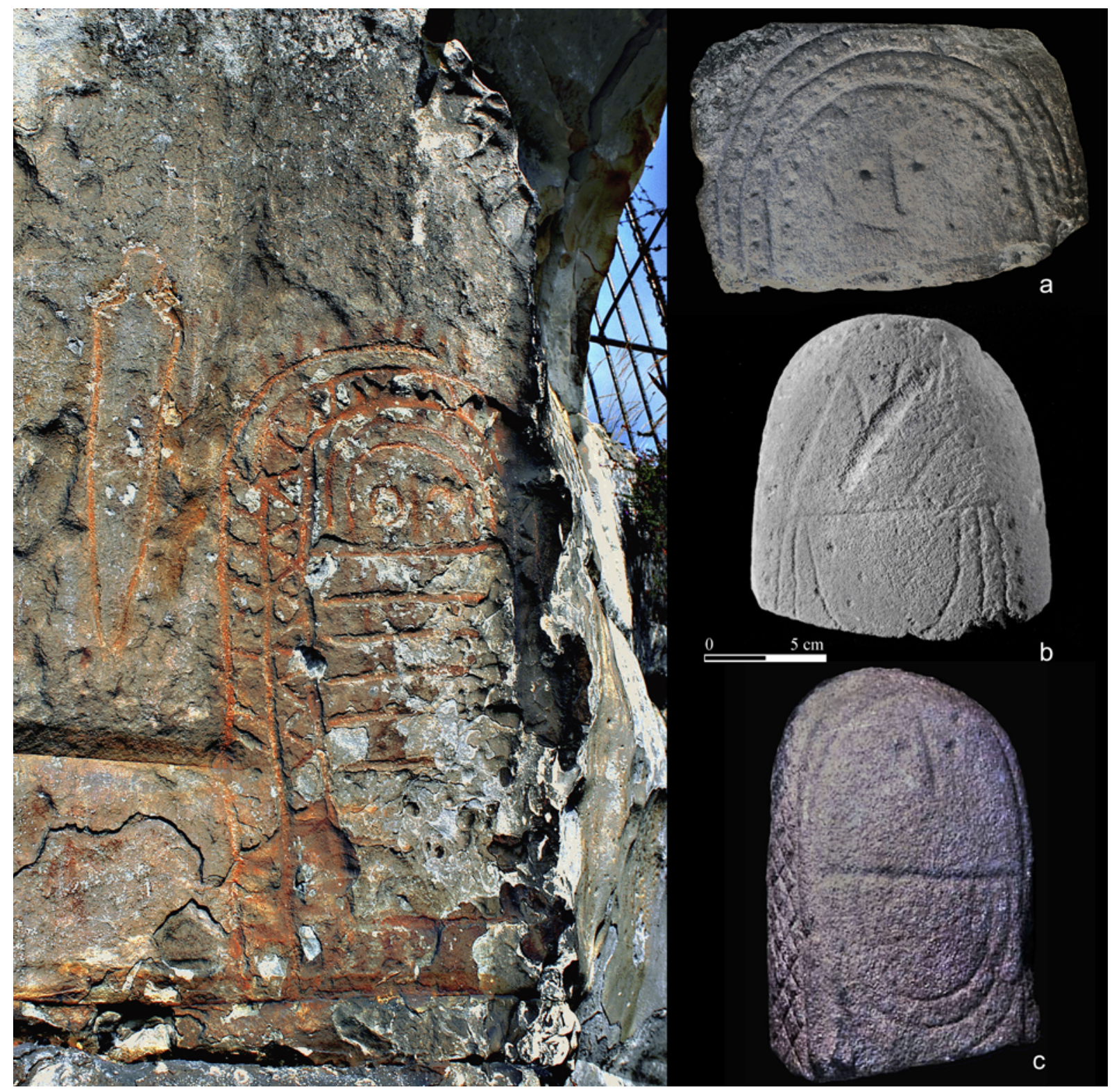

Figure 7. Left: Peña Tú rock shelter with an engraved and painted armed stela. Right: a) Esperança Stela, Lisboa Museum; b) Zebros Stela after Cardoso et al.2002; c) Crato Stela, Lisboa Museum. Photos R. de Balbín Behrmann.

possible clothing is more geometric and can be related to some similar shapes in late megalithic monuments (da Cruz et al. 1998) and to the recent stela of monument 2 of Rochão (Santos and Marques 2007). These add further archaeological confirmation of a third millennium cal BC date for these examples, as previously suggested.

A use that is technically and formally related to the Alentejo stelae is clear in the cut objects that appear at the top of both types. In the stela III, there is possibly an axe handle, because of the width and rounded end of the figure. In the stela I, a fragment of a sword blade can convincingly be related to the abovementioned engraved examples on these stelae. On the other hand, a less common figure combines two elongated trapezoidal shapes interpreted as feet, connected by vertical crosspieces (Gomes and Monteiro 1977: 174). In São Martinho I, only one of the feet shapes and part of the crossing lines can be recognised. The rest have been erased to re-engrave the central emblem. Present

ISSN: 1133-4525 ISSN-e: 2255-3924 http://dx.doi.org/10.12795/spal.2019.i28.17 
Figure 8. São Martinho. Castelo Branco Museum : Up: different views of the stela III. Down: different views of the stela I. Photos R. de Balbín Behrmann.

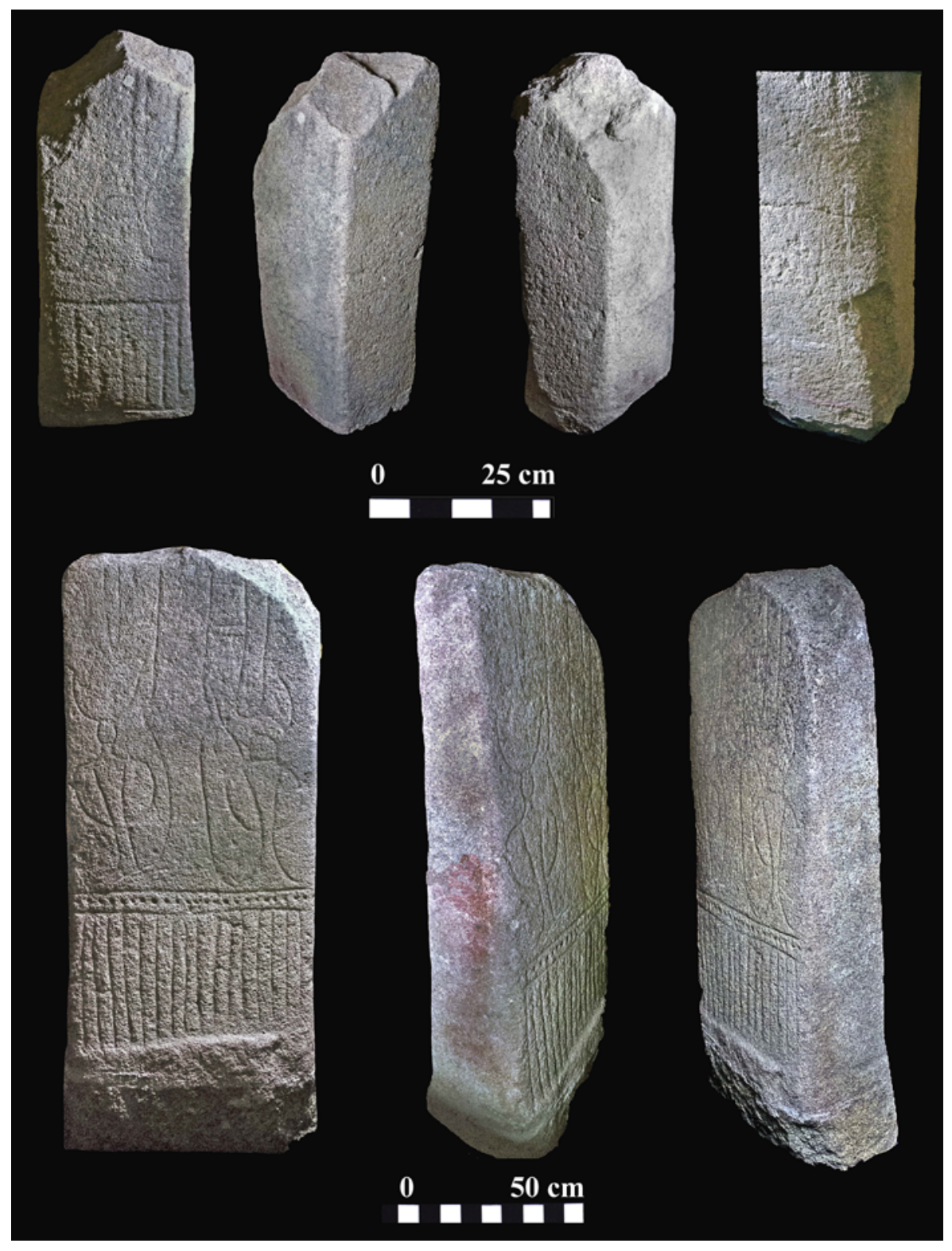

on the stelae of Ervidel 1 and Gomes Aires (Almagro Basch 1966: fig. 41), this image undoubtedly connects with elements that are well defined in the Algarve area. Their chronology (Diaz-Guardamino 2011: 76) coincides with the date mentioned above, with possible extensions in the first half of the second millennium (Bueno et al. 2005a: 623).

Another element shared by both objects is the central emblem. Until recently, the elongated central figure in stela I was regarded as unique within the Late Bronze Age examples (fig. 9). However, in recent years some sites have provided examples that, in their shape and position on the stone, are comparable with this figure. These are the emblems that define the surfaces of some statue-menhir in the Iberian North. Created on menhir-type stones with phallic ends, it is plausible that some of them are reused stones, as previously stated. The documentation of the proximate examples of Nave 1 and 2 provides new points of reference to understand the graphic sequence on the São Martinho stelae.

On the one hand their belts and necklaces display similar designs to those on the central-western stelae, in the surroundings of Granja de Toniñuelo. On the other hand, the emblem is in their centre, as in the case of the 


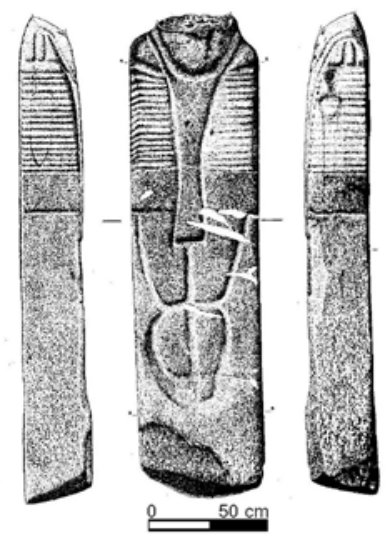

Tremedal

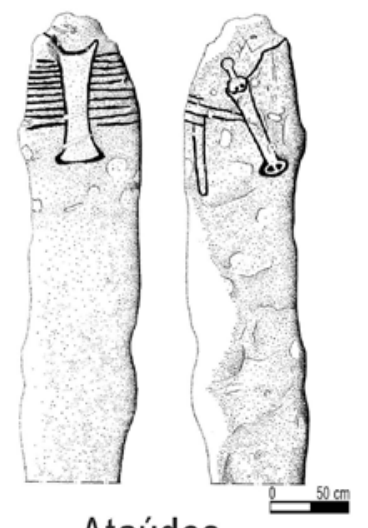

Ataúdes
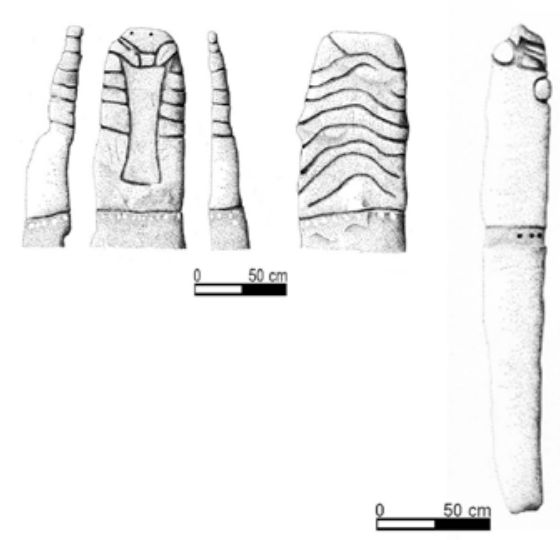

Nave 1

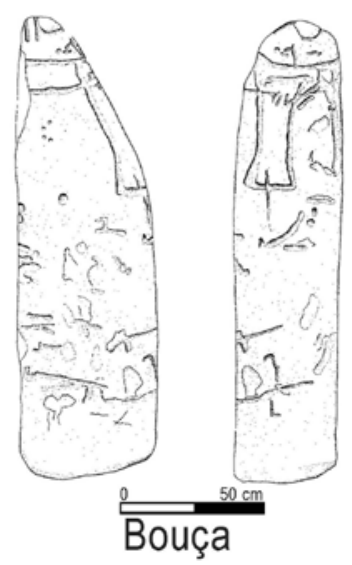

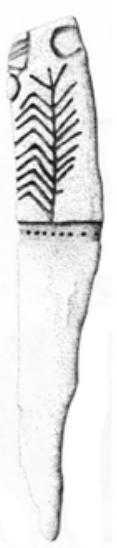

Nave 2
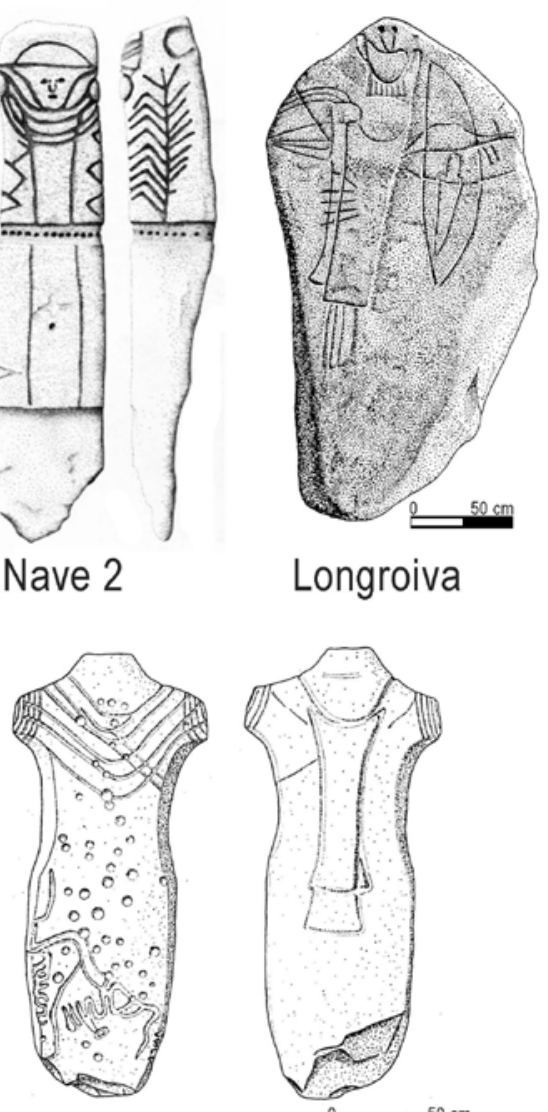

Faioes

Figure 9. Drawings of the armed stelae with the "embleme": Tremedal, Nave 1 and Nave 2, Ataúdes, Bouça and Faiôes, after Lopez Plaza and Sevillano, 1996, Cruz and Santos, 1998; Vilaça et al. 2003.

statue-menhirs in the north of Iberia. They reproduce a shape that resembles the depiction of the body on the Longroiva stela; also with weapons of a third millennium cal BC date. This is an outstanding point of reference. Finally, the lateral engravings resemble sites such as Tremedal and others: third millennium warriors and different clothing or armour. The emblem is in the centre of the Nave 1 and 2 examples and both stones display a noticeable opening at the top. Their endings resemble those of SMI and SMIII at their lower part. The central position is common to other statues in the series, and the relationship of the emblem with a Granja de Toniñuelo-type belt in both cases is another argument supporting links in old engravings. There is one that relates to the central-western stelae and is well represented on stela I. The other one is similar to the Alentejo stelae and the inclusion of the emblem on the two stelae. The sequence of weapons/emblem is present in both cases. Indeed, the evidence of consecutive and non-contemporaneous actions in examples SMI and SMIII of São Martinho suggests variability within the same graphic and chronological framework in a relatively small area. The exclusive determination of chronological sequences by index-fossils is not valid here. The study of the technical and symbolic actions and the contexts in which they appear has provided most of the information. A long period in the third millennium and early second millennium may be suggested for all these versions (Bueno Ramírez 1991, Bueno Ramírez et al. 2005a, 2010a, 2011a).

In any case, stelae I and III at São Martinho demonstrate an intensive use in that chronological framework within which other types of statuary are known in the same area ( Corgas and Ataúdes statues, or the ones at Longroiva, being the most important). It is likely that the third stela at São Martinho, SM II, with its menhir 
shape and phallic carving at the top, was also used during the same period. Moreover, the engravings on the head, made with a completely different technique from those on the front, suggest similarities with protections, especially helmets, like those observed on third millennium Mediterranean statuary. Examples like the Astroki bowl/helmet in gold, display those central geometric drawings with inter-crossing lines that are very similar to the figure at the top of São Martinho II (fig. 10).

Finally the position of these stelae, as proposed by Vilaça (2004b) is also repeated: located in the lower part of the São Martinho Hill, with stela III probably below stela I and possibly abandoned before the latter. Only stela I display graphic evidence of a later reuse, demonstrating its longer prominent position within the site they shared at the foot of São Martinho Hill.

The difference, so often discussed, between the three stelae is nuanced if the techniques and themes on the stelae are studied in detail. They are particularly similar in the graphic solutions adopted for the figures and their helmets. Their size, central position in the panel, the technique employed to depict them, modules used to draw the head, the endings of the feet and the circles associated with the arms are undoubtedly similar, as well as the clothing they wear and the details of the adornments. Establishing that the two figures on stela I and the figure of stela III are very similar is consequent with their technical and graphic resemblances. One of the last times when these stelae were used might have been during the period of the horned helmets warrior's stelae. A chronology between the eleventh and tenth centuries is widely-accepted. Their relationship with Sardinian warriors including even the adornment on their shoulders and their wide-spread presence as far as the Guadiana, are further elements to determine the cultural connections explaining these chieftains' displays of power (Almagro Basch 1966: LXIX, 4) (fig. 11).

The figures on stelae I and III are indeed very alike. In stela I, the similarity of the clothing, helmets, heads and adornments on the shoulders of the figures on each side of the emblem is inescapable. However, it is also a reality that the figure on the viewer's right is more poorly represented both in proportions and in engraving. It has some corrections as well. It was probably shaped by an 'amateur' sculptor or perhaps more quickly. The presence of a circle in the style of a belt buckle recalls evidence from such necropolises as Setefilla, where these adornments appear in association with young individuals, both male and female

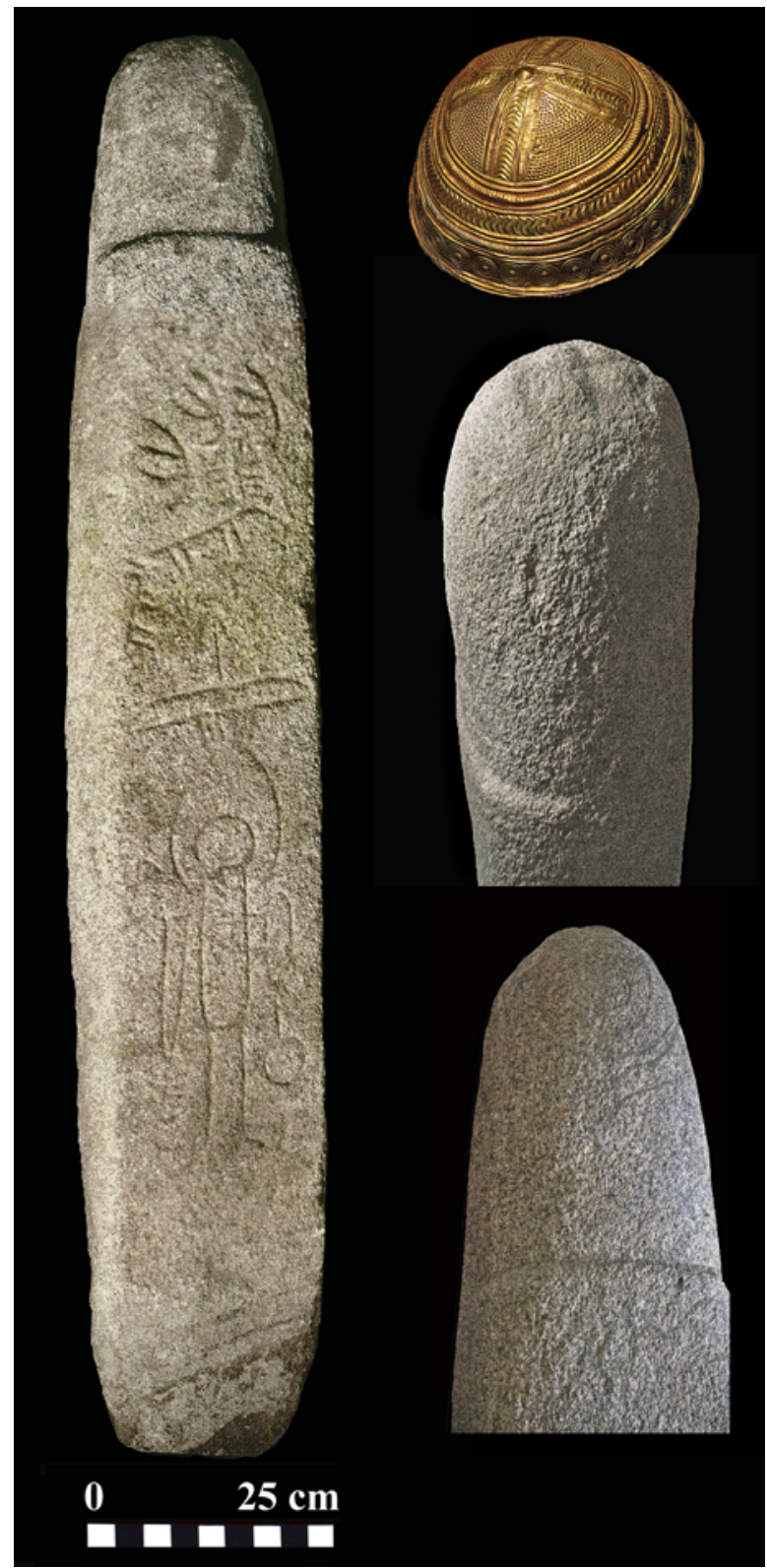

Figure 10. Left: São Martinho II. Menhir. .Castelo Branco Museum, stela II. Right: Astroki gold helmet, National Museum. Madrid. Details of top. Photos R. de Balbín Behrmann.

(Aubet 1997, Barceló 1998). This idea of pairing is relatively frequent in the series from the south-west. The difference in size between the figures has been interpreted as the representation of individuals of different rank. In this case, it can be suggested that they are a young man and a chieftain, or even a woman represented with the attributes of a warrior. 


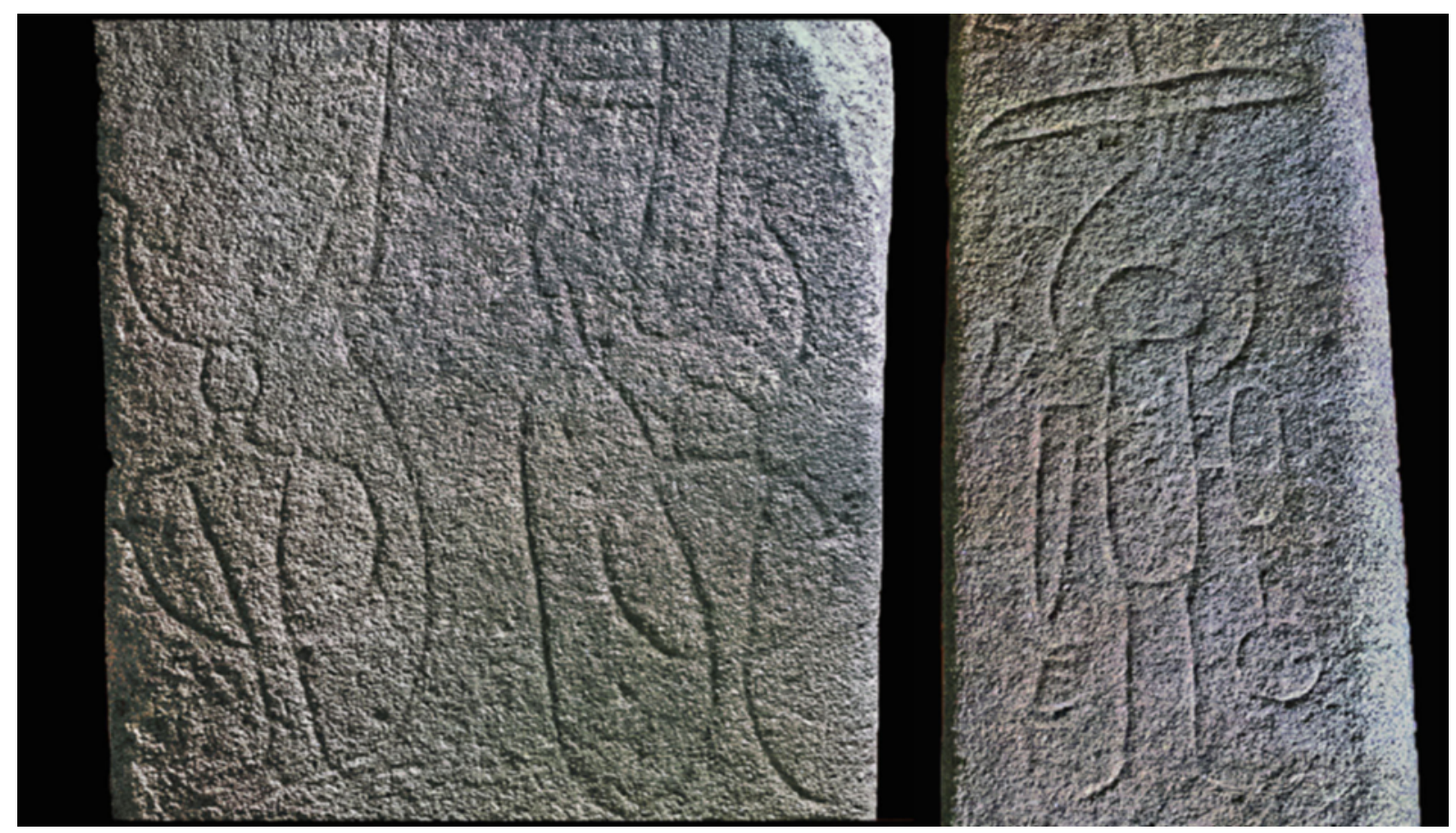

Figure 11. Three warriors detail of Stelae I and II of São Martinho. Castelo Branco Museum. Photos R. de Balbín Behrmann.

The individual on São Martinho II also fits into the Late Bronze Age iconography, although it is part of a hunting scene. The way the raised arms are depicted was also used to draw the possible shields of the warriors on stela I. Their position resembles the horned helmets on the latter stela. This similarity is more plausible when observing the round head, the feathers by the head and the clothing consisting of a belt and a tunic with a zigzag pattern. Clothing represented by incised geometric patterns, as noted by Gomes and Monteiro (1977: fig.7), is supported by our photographic interpretation. It is also a positive element to suggest the great resemblance of the three warrior images found on the two monoliths still standing after the longest time at the foot of São Martinho Hill. The technical and thematic evidence suggests that stelae I and III were fabricated at similar periods in time.

Arrowheads about to be shooting were added to the representations of a stag and birds recalling ancestral images. This calls back to the role of hunting as one of the social characteristics that ennobled the representations of chieftains on these stelae. A scene of this type in Alamillo, Ciudad Real, is associated with individuals with horned helmets. Graphics with a naturalistic tendency described by other authors are distributed as far as the Guadiana (as described above) and are also related to megalithic art reminiscences. One of the birds appears engraved right above a deer's antlers in the picture. Also, another evidence of reuse.

The flipside of both stelae also displays valuable evidence for the persistence of these memories in stone. Stela I display a semi-circular carving that leaves a 10 centimetre in diameter space at the base. The resulting concavity emphasises the shoulders to produce a body on which a necklace and probably a weapon were engraved. Some other examples, such as the of Altea la Vella (Martínez and Sala 2016) in the Spanish Levant are also interesting references to suggest an Iron Age reuse, somewhere around the fifth century, when local deities are the result of images of the past expressing their ancestral strength.The backside of São Martinho II is harder to observe because of the structure that is now supporting it. However, two very schematic human figures are visible, one below the other, in a style with fine incisions and open arms well known in the series of the south-west.

\section{EPILOGUE}

The location of decorated megalithic stones and armed stelae in the Iberian Peninsula has been interpreted as 
evidence of the importance of the West in the cultural definition of Late Prehistory. The Atlantic influence would situate the Iberian megalithic decorations in the north-west. However, the current known distribution places them all across Iberia (Bueno Ramírez et al. 2015d). Armed stelae are equally scattered in the west. Some recent discoveries (Fábregas et al. 2007, Fernández-Eraso et al. 2016, Teira and Ontañón 2016, López and Moyá 2010, Bueno Ramírez et al. 2009a) in addition to those already documented in the north and the east (Almagro Basch 1972, Bueno Ramírez and Fernández Miranda 1981, Durán i Sempere 1970), and examples from the Iberian interior (Santonja and Santonja 1978, López Plaza and Sevillano 1996, Romero Carnicero 1981), suggest that the distribution and density were considerably broader and larger. Late Bronze Age stelae, traditionally centred on the Guadalquivir and Guadiana basins with some extensions towards the Tagus, are now appearing throughout an area very similar to the one described above. The west and centre of the Iberian Peninsula maintain a close relationship with the Atlantic world throughout Late Prehistory. Nevertheless, it did not impede a connection with the Mediterranean. In fact, this dichotomy, emphasised by its geographic position and easy connections across the landscape, in addition to the possibilities for mining, explains the variety of graphic expressions in Iberia which is the most important in Europe nowadays.

Their presence in the megalithic world has become one of the arguments to establish the old age of megaliths' in Brittany (Migdley 2013). Several stones that were used outdoors were the origin for some megalithic monuments. In recent years, research in the Iberian Peninsula has provided with evidence of similar uses, especially in Galicia (Bueno Ramírez et al. 2016), Andalusia (Bueno Ramírez et al. 2009b, 2013, 2015c and 2018b), and the Tagus basin (Bueno Ramírez et al. 2004, 2015b). Further evidence in Catalunya is significant (Bueno Ramírez et al. 2007c, López and Moyá 2010). Furthermore, there is no doubt that reuse of the menhir from the dolmens of Navalcán and Azután (Bueno Ramírez et al. 1999c, 2005b) suggests a very widespread distribution in which menhir and stone stelae played an important role as part of structures that may have been even older than the megaliths (Bueno Ramírez et al. 2017). An early phase of erected large stones during the sixth millennium cal $\mathrm{BC}$ and definitely in the fifth millennium cal BC is coherent with the archaeological information currently available (Bueno Ramírez et al. 2007b).
Radiocarbon dates associated with menhir in the area of the international Tagus, together with information about their secondary use in megalithic monuments, means that this is of an outstanding relevance for the debate. It is one of the clearest areas because of the early Neolithic sites to which some of the mentioned menhir examples are associated (Calado 2002, Oliveira 2015).

Megalithic stones were transformed, reused and adapted to different sequences of use in the monuments, thus becoming the ancestral memory of the first builders. The superimposition of image on image, and the use of stones of similar sizes confirm the importance of ancestral references as part of a ritual exhibition in the Late Bronze Age and Iron Age. Stelae in those periods demonstrate similar ideological backgrounds, justifying the mobility between heroic individuals and images of deities associated with the Iron Age. A sequence of memories that is well documented in other areas of European Prehistory has reached an importance that was previously unsuspected in our area of study (fig. 12)

The new interpretation of the Castelo Branco monuments, together with the new studies that should be carried out for other stelae (particularly those on stones with a 'tradition' in the same area, such as Corgas or Telhado), confirms the need for a modern reassessment. The diachronicity of uses, based on more detailed studies of the stones, can provide evidence of their more than likely long chronologies. These include previous traditions that have not been considered before. The reason why they were dismissed is the influence of colonial ideas as the only and exclusive explanation for the appearance of these records.

The area of study in this paper is an outstanding example within the Iberian archaeological record as a whole because of the diverse typologies that have been documented and their long chronologies. Three aspects that had not been previously considered suggest old reminiscences that support a complex interpretation of these stone monuments:

- The choice of old stones, such as menhir or stelamenhir, on which evidence of reuse is visibly accumulated.

- The use of techniques and typologies for human figures with a long prior tradition.

- Evidence that in some 'cemeteries', the space is shared between older stones and therefore older burials.

The robust inventory of anthropomorphic images between the Tagus and the Douro (which will surely continue to increase in the near future), the existence of 


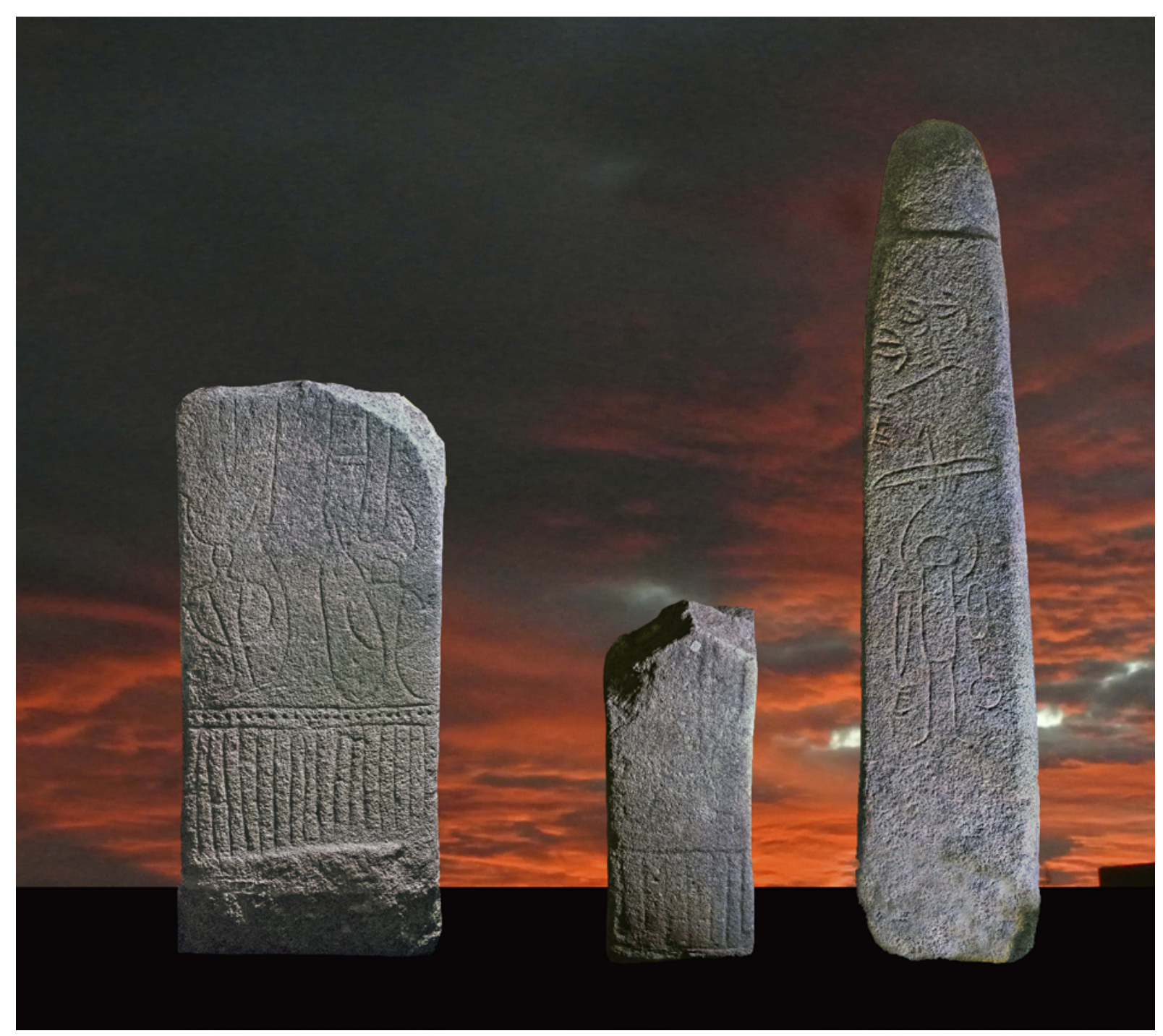

Figure 12. São Martinho ensemble. An idealised view. Photos R. de Balbín Behrmann.

long chronologies from the Neolithic and onwards, the technical and thematic experience of their creators, the 'languages' used on the stones, their association with funerary contexts and habitation sites with prolonged use, etc. All of the above constitute an unquestionable body of evidence to question the idea of 'colonisation' as the sole ideological origin of the south-western stelae. Ideological, material and technical previous availability played an essential role in a social situation where chieftains were competing through the exhibition and acquisition of exotic objects (mostly imported from the Mediterranean area). This competition originated in the first half of the third millennium cal BC. During the Late Bronze Age this ruling class was probably already established and the exhibition of Mediterranean artefacts was reduced to simpler images that demonstrated their possibilities without actually materialising (except on rare occasions). It was class propaganda, or perhaps linages' propaganda, rather than real wealth that was deposited in the burials.

Many questions remain unanswered, but the most noticeable wealth is seen in Andalusian tombs, where there are fewer stelae. In contrast, in mining areas, the number of stelae is larger, but the burials contain less 'flashy' goods. This makes us wonder if the stelae were images of the traders/farmers/metal workers who supplied materials for the elites in the larger/richer burials (probably connected with Phoenician trade). Whatever 
the answer, it is clear that the people, who made the stelae in those areas where they are most abundant, knew and practised a deeply-rooted system of human image representation.

\section{Acknowledgments}

This work was possible thanks to the 2018-099405-BI00 research project granted by the Spanish Ministry of Science, Innovation and Universities. We would like to personally thank the team at the Francisco Tavares de Proença Junior Museum and its Society of Friends. Likewise, we ought to thank the team at the José Monteiro archaeological museum at Fundão This paper was translated by Peter Smith. We would also like to thank the reviewers, whose notes have significantly improved the quality of our work.

\section{REFERENCES}

Almagro Basch, M. (1966): Las estelas decoradas del Suroeste. Madrid, Biblioteca Praehistórica Hispana vol. III. Madrid, Consejo Superior de Investigaciones Científicas.

Almagro Basch, M. (1972): "Los ídolos y la estela decorada de Hernán Pérez (Cáceres) y el ídolo estela de Tabuyo del Monte (León)". Trabajos de Prehistoria 29: 83-112.

Almagro Gorbea, M. (1977): El Bronce Final y el período orientalizante en Extremadura. Madrid, Biblioteca Praehistórica Hispana. Madrid, Consejo Superior de Investigaciones Científicas.

Almeida, F. and da Veiga, O. (1958): "Duas sepulturas megalíticas dos arredores de Idanha-a-Velha". Revista de Guimarães 68 (3-4): 317-322.

Alves, L.B. and Reis, M. (2011): "Memorias de pedra, símbolos de identidade. Duas novas peças escultóricas de Cervos (Montalegre, Vila Real)", in R. Vilaça (ed.), Estelas e Estátuas-menires da Pré à Protohistória: 187-216. Sabugal, Fundação para a Ciência e a Tecnologia.

Araque González, R. (2018): Inter-cultural Communications and Iconography in the Western Mediterranean during the Late Bronze Age and the Early Iron Age. Freiburg, Verlag Marie Leidorf.

Aubet, M. E. (1997): “A propósito de una vieja estela". Saguntum 30: 163-172.

Banha, C.; Mota Veiga, A. and Ferro, S. (2010): “A estátua-menir de Corgas (Donas, Fundão). Contributo para o estudo da Idade do Bronze na Beira Interior". Acafa 2 online. http://www.altotejo.org/acafa/ default2010.asp

Barceló, J.A. (1988): "Introducción al razonamiento estadístico aplicado a la arqueología: un análisis de las estelas antropomorfas de la Península ibérica". Trabajos de Prehistoria 45: 51-85.

Barroso, R.; Bueno-Ramírez, P. and Balbín-Behrmann, R. (2003): "Primeras producciones metálicas en la cuenca interior del Tajo: Cáceres y Toledo". Estudos Pré-históricos 10-11: 87-107.

Barroso, R.; Bueno-Ramírez, P.; Balbín-Behrmann, R. and Lancharro, M. A. (2017): "Production and Consumption of Salt in the Inland Tagus Valley in Prehistory", in M. Bartelheim; P. Bueno-Ramírez and M. Kunst (eds.), Key Resources and Socio-cultural Developments in the Iberian Chalcolithic: 89-105. RessourcenKulturen Band 6, Tübingen, University of Tübingen.

Barroso, R.; Bueno-Ramírez, P.; Camino, J. and Balbín-Behrmann, R. (2007): "Fuentenegroso (Asturias), un enterramiento del Bronce Final - Hierro en el marco de las comunidades atlánticas peninsulares". Pyrenae 38 (2): 7-32.

Beyneix, A. (2007) : "Indices d'un art mégalithique en Aquitaine". Bulletin de la Société Préhistorique Française 104, 3: 517-524.

Bizarro, J.;Vilaça, R.; Pires, H.; Rosa, J. and Baptista, P. (2016): "Estela do Telhado (Fundão)", en Symposium Images in stone in Prehistory and Protohistory: ¿páginas?. Lugar de celebración (año), Braga, ¿editorial?

Bueno-Ramírez, P. (1988): Los dólmenes de Valencia de Alcántara. Excavaciones Arqueológicas en España 155. Madrid, Ministerio de Cultura.

Bueno-Ramírez, P. (1990): "Statues-menhirs et stèles anthropomorphes dans la Péninsule Ibérique". L'Anthropologie 94 (1): 85-110.

Bueno-Ramírez, P. (1991): Megalitos en la Meseta Sur: los dólmenes de Azután y La Estrella (Toledo). Excavaciones Arqueológicas en España 159. Madrid, Ministerio de Cultura.

Bueno-Ramírez, P. (1992): “Les plaques décorées alentejaines: approche de leur étude et analyse". L'Anthropologie 96: 573-604.

Bueno-Ramírez, P. (1995): “Megalitismo, estatuas y estelas en España.Statue-stela e massi incisi nell'Europ dell'etá del Rame". Notizie Archeologiche Bergomensi 3: 77-130.

Bueno-Ramírez, P. (2000): "El espacio de la muerte en los grupos neolíticos y calcolíticos de la 
Extremadura española". Extremadura Arqueológica VIII: $35-80$.

Bueno-Ramírez, P. (2010): “Ancestros e imágenes antropomorfas muebles en el ámbito del megalitismo occidental: las placas decoradas", in Ojos que nunca se cierran. Ídolos en las primeras sociedades campesinas. Madrid, Ministerio de Cultura.

Bueno-Ramírez, P.; Balbín-Behrmann, R. (1991):" La estela del Millarón y su relación con las representaciones antropomorfas megalíticas".XX Congreso Nacional de Arqueología.(Zaragoza,1989). Zaragoza, 1991:199-205

Bueno-Ramírez, P.; Balbín-Behrmann, R.; Barroso, R.; Aldecoa, A. and Casado, A. (1998): "Dólmenes en la Cuenca del Tajo: restauración y consolidación de megalitos en Alcántara (Cáceres)". Trabajos de Prehistoria 55(1): 171-183.

Bueno-Ramírez, P.; Balbín-Behrmann, R.; Barroso, R.; Casado, A. and Aldecoa, A. (1999a): "Proyecto de excavación y restauración en dólmenes de Alcántara, Cáceres, España.”. Trabajos de Prehistoria 56 (1): 131-146.

Bueno-Ramírez, P.; Balbín-Behrmann, R.; Barroso, R.; Aldecoa, A. and Casado, A. (1999b): "Arte megalítico en Extremadura: los dólmenes de Alcántara. Cáceres". Estudos Pré-Históricos 7: 85-110.

Bueno-Ramírez, P.; Balbín-Behrmann, R.; Barroso, R.; Alcolea, J.; Villa, R. and Moraleda, A. (1999c): El dolmen de Navalcán. El poblamiento megalítico en el Guadyerbas. Toledo, Diputación de Toledo.

Bueno-Ramírez, P.; Balbín-Behrmann, R. and Barroso, R. (2004): “Application d'une méthode d'analyse du territoire à partir de la situation des marqueurs graphiques à l'intérieur de la Péninsule Ibérique: le Tage International". L'Anthropologie 108: 653-710.

Bueno-Ramírez, P.; Balbín-Behrmann, R. and Barroso, R. (2005a): "Hierarchisation et métallurgie: statues armées dans la Péninsule Ibérique". L'Anthropologie 109: 577-640.

Bueno-Ramírez, P.; Balbín-Behrmann, R. and Barroso, R. (2005b): El dolmen de Azután (Toledo) Áreas de habitación y áreas funerarias en la cuenca interior del Tajo. Monografías 02. Alcalá de Henares, UAH, Diputación de Toledo.

Bueno-Ramírez, P.; Barroso, R. and Balbín-Behrmann, R. (2006a): "Les mégalithes du centre de la Péninsule Ibérique: une perspective d'analyse à partir de la Meseta Sud", in R. Joussaume, L. Laporte and C. Scarre (eds.), Origine et développement du mégalithisme de l'Ouest de l'Europe Vol. I: 435-450.
Bougon, Conseil général des Deux-Sèvres/Musée des Tumulus de Bougon.

Bueno-Ramírez, P.; Barroso, R.; Balbín-Behrmann, R. and Carrera, F.do (2006b): Megalitos y marcadores gráficos en el Tajo Internacional: Santiago de Alcántara (Cáceres). Santiago de Alcántara, Ayuntamiento de Santiago de Alcántara.

Bueno-Ramírez, P.; Barroso, R. and Balbín-Behrmann, R. (2007a): "El dolmen de Lagunita III: rituales y símbolos de la tradición en el Megalitismo del Tajo Internacional", in Los primeros campesinos campesinos de La Raya. Aportaciones recientes al conocimiento del Neolítico y Calcolítico en Extremadura y Alentejo. Memorias 6: 65-93. Cáceres, Junta de Extremadura.

Bueno-Ramírez, P.; Balbín-Behrmann, R. and Barroso, R. (2007b): "Ideología de los primeros agricultores en el Sur de Europa: las más antiguas cronologías del arte megalítico ibérico". Cuadernos de Arte Rupestre 4: 281-312.

Bueno-Ramírez, P.; Balbín-Behrmann, R. and Barroso, R. (2007c): “Chronologie de l'art Mégalithique ibérique: C14 et contextes archéologiques". L'Anthropologie 111: 590-654.

Bueno-Ramírez, P.; Barroso, R. and Balbín-Behrmann, R. (2008a): "The necropolis of Era de la Laguna, Santiago de Alcántara, Cáceres in the context of the Megalithism of the central region of the International Tagus", in P. Bueno, R. Barroso and R. Balbín (eds.), Graphical Markers and Megalith Builders in the International Tagus, Iberian Peninsula. B.A.R. International series $\mathrm{n}^{\circ}$ 1765: 41-59. Oxford, Archaeopress.

Bueno-Ramírez, P.; Balbín-Behrmann, R. and Barroso, R. (2008b): "Dioses y antepasados que salen de las piedras". Boletín del Instituto andaluz del Patrimonio Histórico 67: 62-67.

Bueno-Ramírez, P.; Balbín-Behrmann, R.; Barroso, R.; López Quintana, J.C. and Guenaga Lisazu, A. (2009a): "Frontières et art mégalithique. Une perspective depuis le monde pyrenéen". L'Anthropologie 113: 882-929.

Bueno-Ramírez, P.; Balbín-Behrmann, R. and Barroso, R. (2009b): “Análisis de las grafías megalíticas de los dólmenes de Antequera y su entorno", in Dólmenes de Antequera: tutela y valorización hoy: 186-197. Sevilla, Instituto Andaluz del Patrimonio Histórico.

Bueno-Ramírez, P.; Barroso, R. and Balbín-Behrmann, R. (2010a): "Metal and the symbols of ancestors in Northern Iberia", in Proceedings of the XV UISPP 
World Congress Vol. 41. BAR International Series 2058: 71-87. Lisbon (2006), Oxford, Archaeopress.

Bueno-Ramírez, P.; Balbín-Behrmann, R.; Barroso, R.; Carrera-Ramírez, F.; Alfonso Carballo, J.; Alonso, J.; Barbado Carreras, J.J.; Berzas Bravo, G.; Martín Expósito, M. A. and Salgado Cilleros, P. (2010b): "Secuencias gráficas paleolítico-postpaleolítico en la Sierra de San Pedro. Tajo Internacional. Cáceres". Trabajos de Prehistoria 67(1): 197-209.

Bueno-Ramírez, P.; Barroso, R. and Balbín-Behrmann, R. (2011a): "Identidades y estelas en el calcolítico peninsular. Memorias funerarias en la cuenca del Tajo", in R. Vilaça (ed.), Estelas e Estátuas-menires da Pré à Protohistória: 37-62. Sabugal, Fundação para a Ciência e a Tecnologia

Bueno-Ramírez, P.; Balbín-Behrmann, R.; Barroso, R.; Cerrillo Cuenca, E.; González Cordero, A. and Prada, A. (2011b): "Megaliths and stelae in the Inner Basin of Tagus river: Santiago de Alcántara, Alconétar and Cañamero (Cáceres, Spain)", in P. Bueno, E. Cerrillo and A. González (eds.), From the Origins: The Prehistory of the Inner Tagus Region, BAR International Series 2219: 143-160. Oxford, Archaeopress.

Bueno-Ramírez, P.; Barroso, R. and Balbín-Behrmann, R. (2012): "Mégalithes, statues, gravures et peintures dans le bassin interieur du Tage, Espagne", in Sépultures collectives et mobiliers funéraires de la fin du Néolithique en Europe occidentale: 333-358. Toulouse, Archives d'Écologie Préhistorique.

Bueno-Ramírez, P.; Balbín-Behrmann, R. and Barroso, R. (2015a): "Graphic programs as ideological construction of the megaliths: the south of the Iberian Peninsula as case study", in L. Rocha; P. BuenoRamírez and G. Branco (eds.), Death as Archaeology of transition:thoughts and materials. British Archaeological Reports. International Series 2078: 52-69. Oxford, Archaeopress.

Bueno-Ramírez, P.; Balbín-Behrmann, R.; Rocha, L.; Oliveira, J. (2015b): “Anthropomorphic images as origins of ancestor's "caves". The stela-menhir of Anta do Telhal, Arraiolos, Evora. Portugal”, in L. Rocha, P. Bueno-Ramírez and G. Branco (eds.), Death as Archaeology of transition: thoughts and materials. British Archaeological Reports. International Series 2078: 83-94. Oxford, Archaeopress.

Bueno-Ramírez, P.; Balbín-Behrmann, R. and Barroso, R. (2015c): "Human images, images of ancestors, identitary images. The South of the Iberian Peninsula", in Statues-menhirs et pierres levées du Néolithique à aujourd 'hui: 443-463. Saint-Ponais, Direction régional des affaires culturelles Languedoc-Rousillon. Groupe Archéologique du Saint-Ponais.

Bueno-Ramírez, P.; Balbín-Behrmann, R.; Laporte, L.; Gouezin, Ph.; Cousseau, F.; Barroso, R.; Hernanz, A.; Iriarte, M. and Quesnel, L. (2015d): "Natural and artificial colors: the megalithic monuments of Brittany". Antiquity 89 (343): 55-71. https://doi. org/10.15184/aqy.2014.29

Bueno-Ramírez, P.; Carrera-Ramirez, F.; Balbín-Behrmann, R.; Barroso, R.; Darriba, X. and Paz, A. (2016): "Stones before stones. Reused stela and menhirs in Galicia megaliths", in Public images private readings: multi-perspective aproches to the Postpalaeolithic Rock art: 1-16. Oxford, Archeopress Archaeology.

Bueno-Ramírez, P.; Balbín-Behrmann, R. and Barroso, R. (2017): "Stelae, Time and Ancestors in the Megaliths of Antequera, Málaga (Spain)". Menga 8: 193-219.

Bueno-Ramírez, P.; Barroso, R. and Balbín-Behrmann, R. (2018a): "El dolmen de Soto 1, entre lo individual y lo colectivo. Estelas armadas", in P. BuenoRamírez, J.A. Linares, R. Balbín-Behrmann and R. Barroso (eds.), Símbolos de la muerte en la Prehistoria Reciente del Sur de Europa. El dolmen de Soto, Huelva. España: 221-231. Sevilla, Junta de Andalucía.

Bueno-Ramírez, P.; Linares, J.A.; Balbín-Behrmann, R. and Barroso, R. (eds.) (2018b): Símbolos de la muerte en la Prehistoria Reciente del Sur de Europa. El dolmen de Soto, Huelva. España. Sevilla, Junta de Andalucía.

Bueno-Ramírez, P.; Balbín-Behrmann, R.; Barroso, R. and Salvado, P. (i.p.): “As estelas de Sao Martinho". Fundão, Ebvrobriga.

Bueno-Ramírez, P. and Fernández Miranda, M. (1981): "El Peñatú de Vidiago (Llanes, Asturias)". Altamira Symposium: 441-458. Santander (1979), Madrid, Ministerio de Cultura.

Bueno-Ramírez, P. and González Cordero, A. (1995): "Nuevos datos para la contextualización arqueológica de estatuas-menhir y estelas antropomorfas en Extremadura". Trabalhos de Antropología e Etnologia 35 (1): 95-106.

Bueno-Ramírez, P. and Vázquez Cuesta, A. (2009): Patrimonio arqueológico de Valencia de Alcántara. Estado de la cuestión. Valencia de Alcántara, Ayto. Valencia de Alcántara. Diputación de Cáceres.

Calado, M. (2002): "Standing stones and natural outcrops: the role of ritual monuments in the Neolithic 
transition of the Central Alentejo", in Ch. Scarre (coord.), Monuments and landscape in Atlantic Europe. Perception and society during the Neolithic and early Bronze: 17-35. London, Routledge.

Caninas, J.; Henriques, F.; Batata, C. and Batista, A. (2004): "Novos dados sobre a Pré-História Recente da Beira Interior Sul. Megalitismo e arte rupestre no Concelho de Oleiros". Estudos Castelo Branco Nova Série 3: 3-30.

Cardoso, J. (2011): “A estela antropomórfica de Monte dos Zebros (Idanha-a-Nova): seu enquadramento nas estelas peninsulares com diademas e "colares", in R. Vilaça (coord.), Estelas e estáuas-menires da Pré à Proto-historia. Actas IV Jornadas Raianas: 89-116. Sabugal, 2009, Sabugal, Fundação para a Ciência e a Tecnologia.

Cardoso, J.L.; Caninas, J. and Henriques, F. (1995a): "A Anta 6 do Couto da Espanhola (Rosmaninhal, Idanha-a-Nova)". Estudos Pré-Históricos III: 1937.

Cardoso, J.L.; Caninas, J. and Henriques, F. (1997): "Contributos para o conhecimiento do megalitismo na Beira Interior (Portugal): A região do Tejo Internacional", in P. Bueno- Ramírez and R. Balbín Behrmann (coords.), Actas del II Congreso de Arqueología peninsular T. II: 207-215. Zamora, 1995, Zamora, Fundación Rei Afonso Henriques.

Cardoso, J.L.; Caninas, J.; Gradim, A.; Nacimiento, J. do. (2002): "Menhires do Alto Algarve oriental: Lavajo I e Lavajo II (Alcoutim)". Revista Portuguesa de Arqueología 5 (2): 99-133.

Cardoso, J.L.; Gomes, M. V.; Caninas, J.; Henriques, J. (1995): "O menir de Cegonhas (Idanha-a-Nova)". Estudos Pre-históricos, vol.III: 5-17.

Cardoso, J.L and, Gradim, A. (2011): Dez anos de trabalhos arqueológicos em Alcoutim. Do Neolítico a o Romano. Lisboa, Câmara Municipal de Alcoutim.

Celestino, S. (2001): Estelas de guerrero y estelas diademadas. La precolonización y formación del mundo tartésico. Barcelona, Bellaterra Arqueología.

Cerrillo Cuenca, E.; Bueno Ramírez, P. and Balbín Behrmann, R. de (2019): ““3DMeshTracings”: A protocol for the digital recording of prehistoric art. Its application at Almendres cromlech (Évora, Portugal)". Journal of Archeological Science: Reports 25: 171.1-183.

Cerrillo Cuenca, E.; Liceras Garrido, R.; Naranjo, J.; Prada, A. and Santos, I. (2015): “Tiempo y paisaje en la necrópolis megalítica de Guadancil (Cáceres)", in L. Rocha, P. Bueno-Ramírez and G. Branco (eds.),
Death as Archaeology of transition:thoughts and materials. British ArchaeologicalReports. International Series 2078: 71-82. Oxford, Archaeopress.

Comendador, B.; Rodríguez, V. and Manteiga, A. (2011): “A estatua menhir do Tameirón no contexto dos resultados do proxecto de intervención arqueolóxica no Monte Urdiñeira e o seu contorno (A Gudiña- Riós, Ourense)", in R. Vilaça (ed.), Estelas e Estátuas-menires da Pré à Protohistória: $217-$ 244. Sabugal, Fundação para a Ciência e a Tecnologia.

Correa, J.A. (2009): "Reflexiones sobre la lengua de las inscripciones en escritura del Sudoeste o Tartesia". Palaeohispanica 9: 295-307.

Cruz, D.J.; Gomes, L. F. and Carvalho, P. M. S. (1998): "O grupo de tumuli da Casinha Derribada (Concelho de Viseu). Resultados preliminares da escavação arqueológica dos monumentos 3,4, e 5". Conimbriga 37: 5-76.

Díaz-Guardamino, M. (2010): Las estelas decoradas en la prehistoria de la Península Ibérica. Madrid, Universidad Complutense de Madrid.

Díaz-Guardamino, M. (2011): "Iconografía, lugares y relaciones sociales: Reflexiones en torno a las estelas y estatuas-menhir atribuidas a la Edad del Bronce en la Península Ibérica)", in R. Vilaça (ed.), Estelas e Estátuas-menires da Pré à Protohistória: 63-83. Sabugal, Fundação para a Ciência e a Tecnologia.

Durán i Sempere, A (1970): "L'estela del Museu de Cervera”. Separata de la Cátedra de Cultura catalana.

Fábregas, R.; Guitián, J.; Gutián, J. and Rodríguez, C. (2007): "Un petroglifo de tipo Outeiro do Corno en Porto do Son (A Coruña)". Gallaecia (26): 55-68.

Fernández Eraso, J.; Arévalo-Muñoz, E.; Camarero, C.; García-Diez, M.; Ochoa Fraile, B. and MujikaAlustiza, J.A. (2016): "Estela decorada en el dolmen del alto de la Huesera (Laguardia, Álava)". Zephyrus LXXVIII: 19-33. https://doi.org/10.14201/ zephyrus2016781933

García Sanjuán, L. and Díaz-Guardamino, M. (2017): "The epigraphic stela of Montoro (Córdoba, Spain): the earliest monumental script in Iberia?". Antiquity 91, 358: 916-932. https://doi.org/10.15184/ aqy. 2017.86

García Sanjuán, L.; Luciañez, M.; Schuhmacher, T.X. and Wheatley, D. (2013): "Ivory craftsmanship, trade and social significance in the southern Iberian Copper Age: the evidence from the PP4-Montelirio sector of Valencina de la Concepción (Seville, Spain)". European Journal of Archaeology 
16 (4): 610-635. https://doi.org/10.1179/14619571 13 Y.0000000037

Gomes, M. V. (2007): “Os periodos iniciais da arte do vale do Tejo (Paleolítico e Epipaleolítico)". Cuadernos de Arte Rupestre 4: 81-116.

Gomes, M. V. and Monteiro, J.P. (1977): "Las estelas decoradas Do Pomar (Beja-Portugal). Estudio comparado". Trabajos de Prehistoria 34: 165-214.

Graefe, J.; Hamon, C.; Lidström-Holmberg,C.;Tsoraki, C. and Watts, S. (2009): "Subsistence, social and ritual practices:quern deposits in the Neolithic societies of Europe", in S. Bonnardin, C. Hamon, M. Lauwers and B. Quilliec (dirs.), Du matériel au spirituel. Réalités archéologiques et historiques de dépôts de la Préhistoire à nos jours. XXIX rencontres Internationales d'archéologie et d'histoire d'Antibes: 29-38. Antibes, 2008. Antibes, Éd. APDCA.

Henriques, F.; Caninas, J.C.; Carvalho, C. N. de and Chambino, M. (2010): "Exploração aurífera antiga no rio Ponsul (Castelo Branco): novos dados", in VI Simpósio Sobre a Mineração e Metalurgia Históricas no Sudoeste Europeu: 307-323. Vila Velha de Rodao, 2010, Vila Velha de Ródão, Carlos Batata.

Henriques, F.; Chambino, M. and Caninas, J.C. (2012): "A estela de guerreiro (lusitano) de Zebros (Idanhaa-Nova)." Sabucale 4: 25-44.

Jones, A.; Cochrane, A.; Carter, Ch.; Dawson, I.; Díaz-Guardamino, M.; Kotoula, E. and Minkin, L. (2015): "Digital imaging and prehistoric imagery: a new analysis of the Folkton Drums". Antiquity 89: 1083-1095. https://doi.org/10.15184/aqy.2015.127

Laporte, L. (2010): "Restauration, reconstruction, appropriation: évolution des architectures mégalithiques dans l'Ouest de la France, entre passé et présent". Munibe suplemento 32: 120-150.

Laporte, L.; Cousseau, F.; Bueno-Ramírez, P.; BalbínBehrmann, R. and Gouezin, Ph. (2017): «Le douziéme dolmen de Barnenez: destructions et reconstructions au sein d'une nécropole mégalithique". Bulletin de la Societé Préhistorique Française 114 (1): 93-114.

López, J. and Moya, A. (2010), "Les estàtues-estelae dels Reguers de Seró (Artesa de Segre, Lleida) i les evidències d'un grup escultòric singular del megalitisme català: el grup de Seró", in Home i territori. Darreres investigacions al Prepirineu lleidatà 2006-2008. 2 Col·loqui d'Arqueologia d'Odèn (El Solsonès): 69-84. Solsona (2010), Solsona, Museu Diocesà i Comarcal de Solsona.
López Plaza, M.S. and Sevillano, M.C. (1996): "Estatua-menhir de Tremedal de Tormes (Salamanca)". Zephyrus 49: 295-303.

Maille, M. (2010): Hommes et femmes de Pierre, Statues-menhirs du Rouergue et du Haut-Languedoc. Toulouse,Archives d'Ecologie Préhistorique.

Martín Bravo, A.M. (1999): Los orígenes de la Lusitania. El I milenio A.C. en la Alta Extremadura. Madrid, Real Academia de la Historia.

Martínez García, J. and Sala, F. (2016): La inmortalidad del guerrero. La estela funeraria ibérica de Altea la Vella. Marq. Museo Arqueológico de Alicante. ¿Lugar de edición?, Ajuntament d'Altea.

Migdley, M.S. (2013): "Megaliths in North-west Europe. The Cosmology of Sacred Lanscapes", in S. Tarlow and L. Nilsson Stutz (eds.), The Archaeology of Death \& Burial: 421-440. Oxford, The Oxford Handboook.

Oliveira, J. (1998): Monumentos megalíticos da bacia hidrográfica do rio Sever. Lisbon, Edições Colibri

Oliveira, J. (2000): "Economia e sociedade dos construtores dos megalitos da bacia do Sever. Neolítico e megalitismo da Península Ibérica", in Actas do 3. ${ }^{\circ}$ Congresso de Arqueología peninsular vol III: 429445. Porto (1999), Porto, ADECAP.

Oliveira, J. (2011): "The early Neolithic of the Coudelaria de Alter in the context of the Megalithism of northern alentejo region-Portugal", in P. Bueno, E. Cerrillo and A. González (eds), From the origins: The Prehistory of the Inner Tagus Region. BAR International Series 2219: 73-82. Oxford, Archaeopress.

Oliveira, J. (2015): “O eterno descaso no Neolítico do Alentejo Norte”, in L. Rocha; P. Bueno-Ramírez and G. Branco (eds.), Death as Archaeology of transition: thoughts and materials. British Archaeological Reports. International Series 2078: 97-106. Oxford, Archaeopress.

Oliveira, J. (2016): "O menir de Patalou, Nisa. Entre contextos e cronologías", in A.C. Sousa, A. Carvalho and C. Viegas (eds.), Terra e agua. Escolher semente, invocar a deusa: 149-167. Estudos e memorias 9. Lisboa, Centro de arqueología de la Universidad de Lisboa.

Oliveira, J. and Oliveira, C.D. (2000): "Menhires del distrito de Portalegre". Extremadura Arqueológica VIII: 105-126.

Oliveira, C.; Bueno-Ramírez, P.; Jiménez, J. C. and Oliveira, J. (2014): "Pinturas esquemáticas en el occidente peninsular: las sierras del Tajo Internacional y los nuevos hallazgos de Valencia de Alcántara", 
in III Simposium Internacional de Arte Rupestre de Habana: 1-19. Habana (2012), Habana, Instituto Cubano de Antropologia.

Robb, J. (2009): "People of Stone: Stelae, Personhood, and Society in Prehistoric Europe". Journal of Archaeological Method and Theory 16: 162-183.

Rocha, L. (2003): "O monumento megalítico do Monte de Tera (Pavía, Mora) Sector 2: resultados das últimas escavaçoes", in Actas do II Colóquio Internacional sobre Megalitismo : 229-349. Reguengos de Monsaraz (2000), Lisboa, Instituto Portugues de arqueología.

Romero Carnicero, F. (1981): "La estatua-menhir de Villar del Ala. Nuevos datos para su estudio". $\mathrm{Nu}$ mantia 1: 115-131.

Salvado, P. and Batista, J (1982): “As gravuras rupestres da anta da Granja de S. Pedro (Idanha-a-Nova. Portugal)", in Coloquio Internacional sobre Arte Esquemático de la Península Ibérica, Resúmenes: s.p. . Salamanca.Salvado, P. and Batista, J. (2016): “A revista" Materiaes para o estudo das antiguidades portuguesas" (1910-2010)". Materiaes 3(1): 153-167.

Santonja, M. and Santonja, M. (1978): "La estatuamenhir de Valdefuentes de Sangusín”. Boletín de la Asociación de Amigos de la Arqueología 10: 19-24.

Santos, A.T. and Marques, J. N. (2007): "Os tumuli do Rochão (Castro Daire, Viseu)". Conimbriga 46: 27-51.

Santos, A.T.; Vilaça, R. and Marques, J.N. (2011): “As estelas do Baraçal, Sabugal (Beira Interior, Portugal)", in R. Vilaça (ed.), Estelas e Estátuas-menires da Pré à Protohistória: 319-342. Sabugal, Fundação para a Ciência e a Tecnologia.

Scarre, Ch.; García Sanjuán, L. and Wheatley, D. (2011): "Exploring time and matter in prehistoric monuments: debating absolute chronology and rare rocks in European megaliths". Menga Monograph $\mathrm{n}^{\mathrm{o}}$ 1: 11-23.

Schuhmacher, T.X. and Banerjee, A. (2012): "Procedencia e intercambio de marfil en el Calcolítico de la Península Ibérica", in Redes en el Neolítico. Circulación e Intercambio de Materias, Productos e Ideas en el Mediterráneo Occidental (VII-III milenio a. C.): 289-298. Gavá, Ajuntament de Gavá.

Soares, J. and Tavares da Silva, C. (2010): “Anta Grade de Zambujeiro. Arquitectura e poder”. Intervençao arqueológica do MAEDS, 1985-87. MUSA 1: 63-129.
Tavares da Silva, C. and Soares, J. (2012): "Castro de Chibanes (Palmela). Do III milénio ao séc. I a.C.”, in Palmela arqueológica no contexto da região inter-estuarina Sado-Tejo: 67-87. Palmela, Câmara Municipal de Palmela.

Teira, L. and Ontañón, R. (2016): “La Estatua-estela de Salcedo (Valderredible) y los inicios del retrato social en la Prehistoria", in Después de Altamira: Arte y grafismo post-paleolítico en Cantabria: 4551. Santander, Acanto.

Vilaça, R. (2000): "Registos e leituras da Pré-história recente e da Prot-história antigua da Beira Interior", in $3^{\circ}$ Congresso de Arqueología Peninsular UTAD: 161-182. Vila Real (1999), Vila Real, ADECAP.

Vilaça, R. (2004a): "Metalurgia do bronze Final no entre Douro e Tejo Portugués: contextos de produção, uso e deposição", in Actas del Congreso Ambitos tecnológicos, ámbitos de poder. La transición Bronce Final - Hierro en la Península Ibérica: 1-12. Madrid (2004), Madrid, CSIC.

Vilaça, R. (2004b): "O monte de S. Martinho. Castelo Branco, na Idade do Bronze". Arqueología: colecções de Francisco Tabares de Proença Junior: 55-61. Castelo Branco, Instituto Portugués de Museus.

Vilaça, R. (2013) : “L'arrivée des premiers fers dans l'Occident atlantique". Mélanges de la Casa de Velázquez. Nouvelle série, 43 (1): 39-64.

Vilaça, R.; Cruz, D. da; Santos, A. and Marques, J.N. (2003): "A statue menhir from Ataúdes (Figueira de Castelo Rodrigo, Guarda. Portugal): a first notice", in I Congresso Internacional de Arqueología iconográfica e Simbólica: 104-119. Patrimonio de Valle do Côa, Vila Nova de Foz Coa, Meda e Vale do Côa, 2002.

Vilaça, R.; Osório, M. and Santos, A.T. (2011b): "Nova peça insculturada da regiao raiana do Sabugal (Beira Interior, Portugal): uma primeria abordagem", in R. Vilaça (ed.), Estelas e Estátuas-menires da Pré à Protohistória: 343-367. Sabugal, Fundação para a Ciência e a Tecnologia.

Vilaça, R.; Santos, A.T. and Gomes, S. M. (2011a): "As estelas de Pedra da Atalaia (Celorico da Beira, Guarda) no seu contexto geo-arqueológico", in R. Vilaça (ed.), Estelas e Estátuas-menires da Pré à Protohistória: 293-318. Sabugal, Fundação para a Ciência e a Tecnologia. 